\title{
Technological feasibility and costs of achieving a $50 \%$ reduction of global GHG emissions by 2050: mid- and long-term perspectives
}

\author{
Osamu Akashi • Tatsuya Hanaoka
}

Received: 6 July 2011/Accepted: 3 April 2012/Published online: 26 April 2012

(C) The Author(s) 2012. This article is published with open access at Springerlink.com

\begin{abstract}
In this article we examine the technological feasibility of the global target of reducing GHG emissions to $50 \%$ of the 1990 level by the year 2050. We also perform a detailed analysis of the contribution of low-carbon technologies to GHG emission reduction over mid- and long-term timeframes, and evaluate the required technological cost. For the analysis we use AIM/Enduse[Global], a technoeconomic model for climate change mitigation policy assessment. The results show that a $50 \%$ GHG emission reduction target is technically achievable. Yet achieving the target will require substantial emission mitigation efforts. The GHG emission reduction rate from the reference scenario stands at $23 \%$ in 2020 and $73 \%$ in 2050 . The marginal abatement cost to achieve these emission reductions reaches $\$ 150 / \mathrm{tCO}_{2}$-eq in 2020 and $\$ 600 / \mathrm{tCO}_{2}$-eq in 2050 . Renewable energy, fuel switching, and efficiency improvement in power generation account for $45 \%$ of the total GHG emission reduction in 2020. Non-energy sectors, namely, fugitive emission, waste management, agriculture, and F-gases, account for $25 \%$ of the total GHG emission reduction in 2020. CCS, solar power generation, wind power generation, biomass power generation, and biofuel together account for $64 \%$ of the total GHG emission reduction in 2050. Additional investment in GHG abatement technologies for
\end{abstract}

Handled by Tatsuya Hanaoka, National Institute for Environmental Studies, Japan.

O. Akashi ( $\square)$

Musashino University, 3-3-3 Ariake, Koto-ku,

Tokyo 135-8181, Japan

e-mail: o_akashi@musashino-u.ac.jp

O. Akashi · T. Hanaoka

National Institute for Environmental Studies,

16-2 Onogawa, Tsukuba, Ibaraki 305-8506, Japan achieving the target reaches US\$ 6.0 trillion by 2020 and US\$ 73 trillion by 2050 . This corresponds to 0.7 and $1.8 \%$ of the world GDP, respectively, in the same periods. NonAnnex I regions account for $55 \%$ of the total additional investment by 2050. In a sectoral breakdown, the power generation and transport sectors account for 56 and $30 \%$ of the total additional investment by 2050 , respectively.

Keywords Climate change - Emission reduction . Technology $\cdot$ Cost $\cdot 2020 \cdot 2050$

\section{Introduction}

Ambitious long-term ${ }^{1}$ climate targets are being seriously considered in international climate policy arenas. Under the Cancun agreements concluded at the 16th session of the Conference of the Parties (COP16), for example, the conference of parties recognizes the long-term climate goal of holding the increase in global average temperature below $2{ }^{\circ} \mathrm{C}$ above pre-industrial levels. At the G8 summit held in L'Aquila in 2009, the leaders of the G8 countries agreed to share the goal of achieving at least a $50 \%$ reduction of global emissions by 2050 .

Climate change mitigation models have been used to explore GHG emission reduction scenarios. In its Fourth Assessment Report (AR4), the Intergovernmental Panel on Climate Change (IPCC) reviewed 177 emission mitigation scenarios and classified them into six categories based on the stringency of the climate targets (IPCC 2007). According to the classification, the global temperature target of $2{ }^{\circ} \mathrm{C}$ and the emission reduction target of $50 \%$ by

\footnotetext{
${ }^{1}$ In this article, 'mid-term' refers to the period up to 2030 and 'longterm' refers to the period beyond 2030, unless otherwise noted.
} 
Table 1 Classification of emission mitigation scenarios according to different stabilization targets (IPCC 2007)

\begin{tabular}{|c|c|c|c|c|c|c|c|}
\hline Category & $\begin{array}{l}\text { Additional } \\
\text { radiative } \\
\text { forcing (W/ } \\
\mathrm{m}^{2} \text { ) }\end{array}$ & $\begin{array}{l}\mathrm{CO}_{2} \\
\text { concentration } \\
(\mathrm{ppm})\end{array}$ & $\begin{array}{l}\mathrm{CO}_{2} \text {-eq } \\
\text { concentration } \\
(\mathrm{ppm})\end{array}$ & $\begin{array}{l}\text { Global mean temperature increase } \\
\text { above pre-industrial at equilibrium } \\
\text { using best estimate climate sensitivity } \\
\left({ }^{\circ} \mathrm{C}\right)\end{array}$ & $\begin{array}{l}\text { Peaking } \\
\text { year for } \\
\mathrm{CO}_{2} \\
\text { emissions }\end{array}$ & $\begin{array}{l}\text { Change in global } \\
\mathrm{CO}_{2} \text { emissions in } \\
2050 \text { (\% of } 2000 \\
\text { emissions) }\end{array}$ & $\begin{array}{l}\text { No. of } \\
\text { assessed } \\
\text { scenarios }\end{array}$ \\
\hline I & $2.5-3.0$ & $350-400$ & $445-490$ & $2.0-2.4$ & 2000-2015 & -85 to -50 & 6 \\
\hline II & $3.0-3.5$ & $400-440$ & $490-535$ & $2.4-2.8$ & 2000-2020 & -60 to -30 & 18 \\
\hline III & $3.5-4.0$ & $440-485$ & $535-590$ & $2.8-3.2$ & 2010-2030 & -30 to +5 & 21 \\
\hline IV & $4.0-5.0$ & $485-570$ & $590-710$ & $3.2-4.0$ & $2020-2060$ & +10 to +60 & 118 \\
\hline V & $5.0-6.0$ & $570-660$ & $710-855$ & $4.0-4.9$ & $2050-2080$ & +25 to +85 & 9 \\
\hline VI & $6.0-7.5$ & $660-790$ & $855-1130$ & $4.9-6.1$ & 2060-2090 & +90 to +140 & 5 \\
\hline Total & & & & & & & 177 \\
\hline
\end{tabular}

2050 correspond to the most stringent category, category I (Table 1).

In the scenarios in category $\mathrm{I}, \mathrm{CO}_{2}$ emissions peak in $2000-2015$ and drop to -85 to $-50 \%$ in 2050 relative to the 2000 level. While these results certainly furnish policymakers with valuable information, one should be mindful of their robustness. The number of scenarios in category I is quite limited, accounting for only 6 out of all 177 scenarios assessed. To make up for this limitation, the modeling community has been actively exploring low climate stabilization scenarios after the AR4. EMF 22, for example, considered the GHG concentration stabilization target of $450 \mathrm{ppm} \mathrm{CO}_{2}$-eq and examined the achievability of this target under different international mitigation policies and emission pathways (Clarke et al. 2009). The ADAM project analyzed the technical feasibility and economic viability of the $2{ }^{\circ} \mathrm{C}$ target (Edenhofer et al. 2010). The RECIPE project assessed the achievability of a $\mathrm{CO}_{2}$ concentration target of $450 \mathrm{ppm}$ (a level roughly corresponding to 530-550 $\mathrm{ppm} \mathrm{CO}_{2}$-eq) and examined how technology and international policy frameworks influenced this achievability (Luderer et al. 2011). The main objective of these existing studies is to assess the longterm (up to 2100) technical feasibility and economic viability of low stabilization targets from a macroscopic perspective. Detailed assessments of the technologies were therefore outside the scope of the studies. Only a few groups so far have conducted detailed technological assessments in stringent climate target scenarios (IEA 2010, for example). As such, a detailed understanding of technologies within a long-term stringent GHG mitigation scenario is still awaited. A mid-term perspective is also required. According to UNEP (2010), the pledged mid-term emission reductions still fall far below the actual mid-term emission reduction required to meet the longterm climate target of $2{ }^{\circ} \mathrm{C}$. To bridge this gap, a mitigation study needs to describe a mid-term perspective that aligns consistently with the long-term goal.

In this study we use a techno-economic approach to examine the technological feasibility of a global reduction of GHG emissions by $50 \%$ relative to the 1990 level by
2050, a target that roughly corresponds to the climate target of $2{ }^{\circ} \mathrm{C}$. We also perform a detailed analysis of the contribution of low-carbon technologies to GHG emission reduction in the mid- and long-term and evaluate the required technological cost. ${ }^{2}$

\section{Methodology}

\section{AIM/Enduse[Global]}

The analysis in this paper uses AIM/Enduse[Global], a techno-economic model for mid- to long-term climate change mitigation policy assessment. AIM/Enduse[Global] is a dynamic recursive model with a 1-year time step and a detailed framework for technology selection. The model selects technologies by linear programming algorithms that minimize the total system cost (including the initial investment, operation, and maintenance costs of technologies, energy cost, and other costs such as carbon tax) given fixed service demands such as steel production, passenger transport, space heating demand, etc. The model estimates energy consumption and $\mathrm{GHG}$ emissions (e.g., $\mathrm{CO}_{2}, \mathrm{CH}_{4}$, $\mathrm{N}_{2} \mathrm{O}, \mathrm{HFC}, \mathrm{PFC}$, and $\mathrm{SF}_{6}$ ) driven by technological change. Kainuma et al. (2003) provide a detailed formulation of the model.

The version of AIM/Enduse[Global] used in this article splits the world into 32 regions over a time horizon from 2005 to 2050. It covers energy sectors through the phases of energy production to end-use, and non-energy sectors, including agriculture, waste, and F-gases (Fig. 1). Emission

\footnotetext{
2 An important step, for long-term energy planning, is to evaluate the energy system from a risk management perspective. Currently, in the aftermath of the nuclear power reactor accident in Fukushima, the assessment of environmental and social risks associated with technological and natural uncertainties is thought to be particularly important. Yet this type of assessment lies outside the scope of this study. Instead, we focus on the costs and mitigation potentials of lowcarbon technologies.
} 
Fig. 1 Overview of AIM/ Enduse[Global]

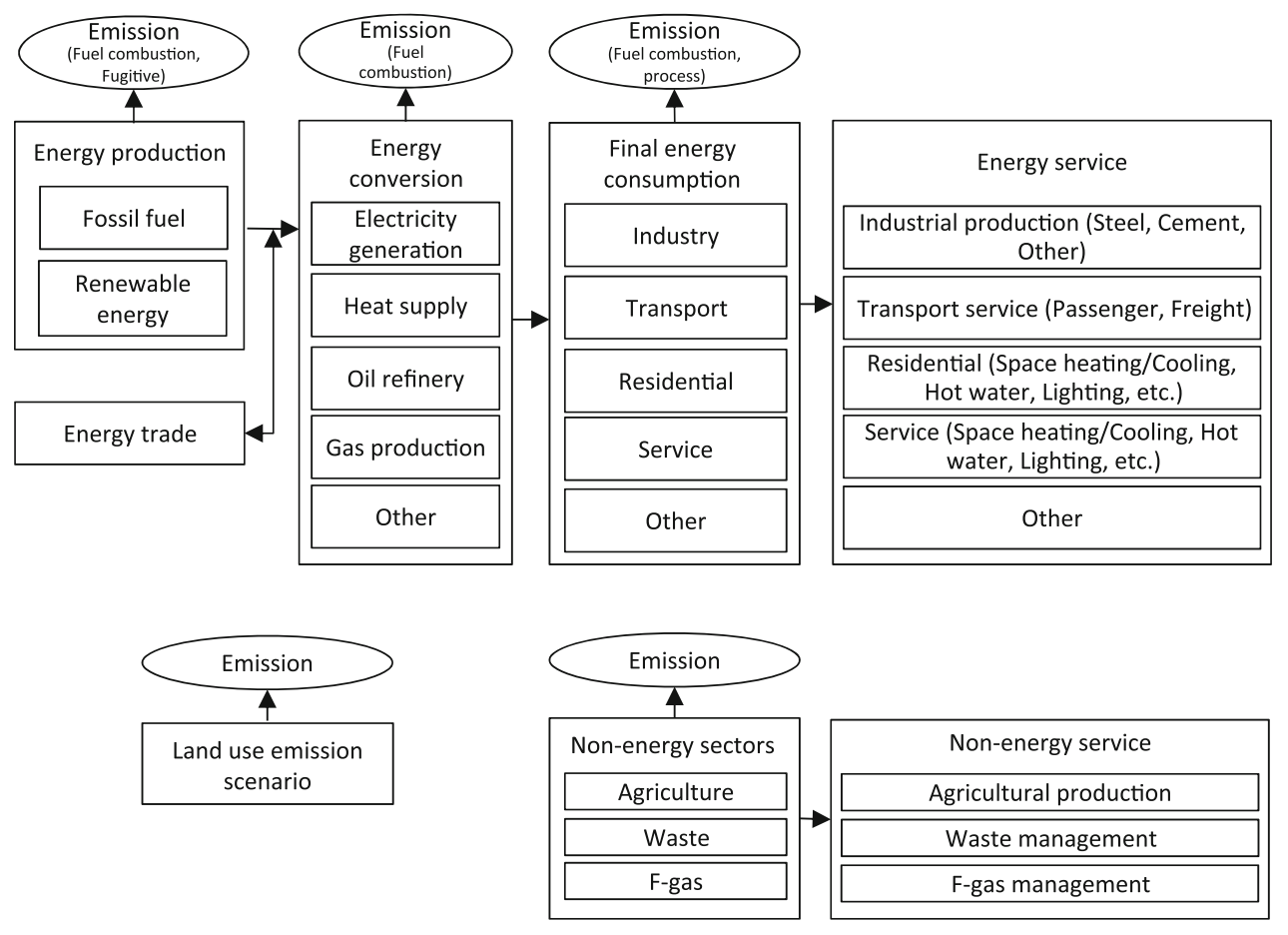

becomes the world's largest steel producer in 2050. Global cement production in 2050 reaches 2.0 times the production level in 2005. China remains the largest cement producer up to 2050, but India has the highest rate of growth. Passenger and freight transport volume grow by about $2 \% /$ year worldwide on average between 2005 and 2050, and the growth is especially fast in China and India. Industrialized regions have moderate rates of growth in industrial production and transport volume, as a consequence of relatively low rates of economic growth. Industrial production and transport volume decline in the long term in Japan, which has a decreasing population and the lowest rate of economic growth.

Key assumptions on the availability of resources and technologies

The model simulation is subject to assumptions on the availability of energy resources and key technologies. This section describes the model's assumptions on the availability of renewable energy, nuclear power, and carbon dioxide capture and storage (CCS).

The potential of solar and wind power depends on natural conditions such as insolation, wind, and geography. We evaluate the power generation potentials of solar and wind by conducting a geographically explicit analysis. The detailed methodology for this approach is provided in Masui et al. (2010). The estimated total technical potential, after considering the conversion efficiency and suitability of the land, is $166 \mathrm{PWh}$ for solar and $47 \mathrm{PWh}$ for wind
3 Bioenergy supply is assumed to cause no major land use change or additional $\mathrm{CO}_{2}$ emission in any of the scenarios in this study. See "Key assumptions on the availability of resources and technologies" for more detail. 
Table 2 List of technologies considered in AIM/Enduse[Global]

\begin{tabular}{|c|c|c|}
\hline Sector & Category & Technology options \\
\hline \multirow[t]{4}{*}{ Power generation } & Coal & $\begin{array}{l}\text { Pulverized coal combustion (PCC), supercritical PCC (SC-PCC), ultra-supercritical PCC } \\
\text { (USC-PCC), advanced ultra-supercritical PCC (AUSC-PCC), integrated gasification } \\
\text { combined cycle (IGCC), SC-PCC with carbon capture and storage (CCS), USC-PCC with } \\
\text { CCS, AUSC-PCC with CCS, IGCC with CCS }\end{array}$ \\
\hline & Oil & Combined cycle (CC) \\
\hline & Gas & Combined cycle (CC), advanced combined cycle (ACC) [level 1-2], ACC with CCS \\
\hline & Renewables & $\begin{array}{l}\text { Hydropower, wind power [level 1-3], wind power with storage battery [level 1-3], } \\
\text { photovoltaics [level 1-4], photovoltaics with storage battery [level 1-4], biomass power } \\
\text { plant, biomass IGCC, biomass IGCC with CCS }\end{array}$ \\
\hline $\begin{array}{l}\text { Hydrogen } \\
\text { production }\end{array}$ & & Coal, coal with CCS, natural gas, natural gas with CCS, biomass, biomass with CCS \\
\hline \multirow[t]{3}{*}{ Industry } & Steel & $\begin{array}{l}\text { Coke oven (e.g., large-sized coke oven, coke gas recovery, automatic combustion, coal wet } \\
\text { adjustment, coke dry type quenching, COG latent heat recovery, next generation coke oven), } \\
\text { sinter furnace (e.g., automatic igniter, cooler waste heat recovery, mainly waste heat } \\
\text { recovery, efficient igniter), blast furnace (e.g., large-size blast furnace, blast furnace gas } \\
\text { recovery, blast furnace gas recovery with CCS, wet top pressure recovery turbine, dry top } \\
\text { pressure recovery turbine, heat recovery of hot blast stove, coal injection, dry top pressure } \\
\text { gas recovery), basic oxygen furnace (e.g., LDG recovery, LDG latent heat recovery), casting } \\
\text { and rolling (e.g., continuous caster, hot charge rolling, hot direct rolling, efficient heating } \\
\text { furnace, heat furnace with regenerative burner, continuous annealing lines), electric furnace } \\
\text { (e.g., DC electric furnace, scrap pre-heat) }\end{array}$ \\
\hline & Cement & $\begin{array}{l}\text { Mill (e.g., ball mill, tube mill, vertical mill), kiln (e.g., wet kiln, semi-wet/dry kiln, dry long } \\
\text { kiln, vertical shaft kiln, SP/NSP, advanced kiln with CCS) }\end{array}$ \\
\hline & Other industries & $\begin{array}{l}\text { Boiler [level 1-5] [e.g., efficient boiler (coal, oil, gas), boiler with combustion control (coal, } \\
\text { oil, gas), cogeneration (coal, oil, gas), regenerative gas boiler], process heat [e.g., efficient } \\
\text { industrial furnace (oil, gas)], motors [level 1-2] (e.g., motor with inverter control, efficient } \\
\text { motor) }\end{array}$ \\
\hline \multirow[t]{7}{*}{$\begin{array}{l}\text { Residential and } \\
\text { commercial }\end{array}$} & Cooling & $\begin{array}{l}\text { Efficient air conditioner [level 1-3] (e.g., sold average in developed countries in 2005, top } \\
\text { runner, highest performance) }\end{array}$ \\
\hline & Warming & $\begin{array}{l}\text { Efficient air conditioner [level 1-3] (e.g., sold average in developed countries in 2005, top } \\
\text { runner, highest performance), thermal insulation (e.g., wall insulation for detached house, } \\
\text { wall insulation, double-glazed glass with low-e) }\end{array}$ \\
\hline & Hot water & $\begin{array}{l}\text { Efficient water heater (kerosene, LPG, gas, coal), latent heat recovery water heater (kerosene, } \\
\text { LPG, gas), } \mathrm{CO}_{2} \text { refrigerant heat pump water heater [level 1-3], solar thermal water heater, } \\
\text { electric water heater, fuel cell }\end{array}$ \\
\hline & Cooking & Efficient cooking stove (kerosene, LPG, gas, coal), electric IH cooker \\
\hline & Lighting & $\begin{array}{l}\text { Efficient fluorescent lamp [level 1-2], efficient compact fluorescent lamp [level 1-2], LED } \\
\text { lamp }\end{array}$ \\
\hline & Refrigerator & $\begin{array}{l}\text { Efficient refrigerator [level 1-3] (sold average in developed countries in 2005, top runner, } \\
\text { highest performance) }\end{array}$ \\
\hline & TV & $\begin{array}{l}\text { Efficiency TV [level 1-3] (sold average in developed countries in 2005, top runner, highest } \\
\text { performance), liquid crystal display TV }\end{array}$ \\
\hline \multirow[t]{6}{*}{ Transport } & Passenger car & $\begin{array}{l}\text { Efficient vehicle [level 1-3] (gasoline, diesel) [e.g., weight reduction, engine friction } \\
\text { reduction, aerodynamic drag reduction, rolling resistance reduction, brake drag reduction, } \\
\text { continuously variable transmission (CVT), variable valve life and time (VVLT) and cylinder } \\
\text { reactivation, direct injection], hybrid electric vehicle (HEV) (gasoline, diesel), plug-in HEV } \\
\text { (gasoline, diesel), electric passenger vehicle (EV), fuel-cell passenger vehicle (FCV), biofuel }\end{array}$ \\
\hline & Truck & $\begin{array}{l}\text { Efficient small-sized truck (e.g., rolling resistance reduction, engine improvement, weight } \\
\text { reduction, aerodynamic drag reduction), hybrid small-sized vehicle, small-sized electric } \\
\text { vehicle, small-sized fuel cell vehicle, efficient large-sized truck, hybrid large-sized vehicle, } \\
\text { natural gas vehicle, biofuel }\end{array}$ \\
\hline & Passenger bus & Efficient bus (e.g., rolling resistance reduction, engine improvement), hybrid bus, biofuel \\
\hline & Ship & Efficient ship, biofuel \\
\hline & Aircraft & Efficient aircraft (e.g., engine improvement, weight reduction, drag reduction), biofuel \\
\hline & Rail & Efficient train (electricity, diesel) (e.g., regenerative braking system with VVVF) \\
\hline
\end{tabular}


Table 2 continued

\begin{tabular}{|c|c|c|}
\hline Sector & Category & Technology options \\
\hline \multirow[t]{4}{*}{ Agriculture } & Rice cultivation & $\begin{array}{l}\text { Water management (e.g., midseason drainage, shallow flooding, alternative flooding and } \\
\text { drainage), fertilizer management (e.g., ammonium sulphate, addition of phosphogypsum), } \\
\text { cultivation management (e.g., upland rice, direct wet seeding, off-season straw), rice straw } \\
\text { compost }\end{array}$ \\
\hline & Cropland & $\begin{array}{l}\text { Fertilizer management (e.g., reduce fertilization, nitrogen inhibitor, spreader maintenance, } \\
\text { split fertilization, sub-optimal fertilizer application), replacing fertilizer (e.g., replacing } \\
\text { fertilizer with manure-N and residue), cultivation management (e.g., fertilizer free zone, } \\
\text { optimize distribution geometry, convert fertilizational tillage to no-till), water management } \\
\text { (e.g., irrigation, drainage) }\end{array}$ \\
\hline & Mature management & $\begin{array}{l}\text { Anaerobic digestion (e.g., centralized plant, farm-scale plant), covered lagoon (e.g., farm use, } \\
\text { household use), biogas use for cook and light from domestic storage, manure treatment (e.g., } \\
\text { daily spread of manure, slowing down anaerobic decomposition), fixed-film digester, plug } \\
\text { flow digester }\end{array}$ \\
\hline & Livestock rumination & $\begin{array}{l}\text { Chemical substance management (e.g., propionate precursors, probiotics, antibiotics, } \\
\text { antimethanogen, methane oxidizers), feed management (e.g., improve feed conversion, } \\
\text { improved feeding practices, high fat diet, replace roughage with concentrates), genetic (e.g., } \\
\text { high genetic merit, improved feed intake and genetics) }\end{array}$ \\
\hline Waste & Municipal solid waste & $\begin{array}{l}\text { Biological treatment, improved oxidation through improved capping and restoration, direct use } \\
\text { (e.g., direct use of landfill gas, electricity and heat generation from landfill gas, upgrade } \\
\text { natural gas), flaring landfill gas, anaerobic digestion, composting (e.g., windrow plant, tunnel } \\
\text { plant, hall plant), incineration, paper recycling, production of RTD (refuse-derived fuel) }\end{array}$ \\
\hline $\begin{array}{l}\text { Fugitive } \\
\text { emissions }\end{array}$ & $\begin{array}{l}\text { Fugitive emissions from } \\
\text { fuel production }\end{array}$ & $\begin{array}{l}\text { Coal mining (e.g., degasification for natural gas pipeline injection, degasification for } \\
\text { electricity, ventilation for electricity, ventilation oxidizer for heat), natural gas production } \\
\text { and distribution (e.g., use of instrument air, use of low bleed pneumatic devices), crude oil } \\
\text { production (e.g., flaring in place of venting, direct use of } \mathrm{CH}_{4} \text {, reinjection of } \mathrm{CH}_{4} \text { ) }\end{array}$ \\
\hline \multirow{8}{*}{$\begin{array}{l}\text { Fluorinated gas } \\
\text { emissions }\end{array}$} & By-product emissions & Thermal oxidation \\
\hline & Refrigerants & $\begin{array}{l}\text { Alternative system (e.g., carbon dioxide, hydrocarbons, hydrocarbons and } \mathrm{NH}_{3} \text { ), leakage } \\
\text { reduction (e.g., for mobile air conditioning, commercial refrigeration, industrial } \\
\text { refrigeration, stationary air conditioning DX, stationary air conditioning chiller), recovery } \\
\text { (e.g., for mobile air conditioning, domestic refrigeration), decomposition }\end{array}$ \\
\hline & Aerosols & $\begin{array}{l}\text { Alternative aerosol (e.g., hydrocarbon aerosol propellants, not-in-kind alternatives), } 50 \% \\
\text { reduction (e.g., for medical applications, general aerosol propellants) }\end{array}$ \\
\hline & Foams & $\begin{array}{l}\text { Recovery, decomposition, alternative system (e.g., water-blown } \mathrm{CO}_{2} \text { systems, liquid } \mathrm{CO}_{2} \\
\text { foam blowing, hydrocarbon foam blowing) (for residential buildings, commercial buildings) }\end{array}$ \\
\hline & Solvents & Alternative solvents (e.g., NIK aqueous, NIK semi-aqueous), retrofit options, $50 \%$ reduction \\
\hline & Manufacturing & $\begin{array}{l}\text { Semiconductor manufacturing (e.g., cleaning facility, recapture/destroy, plasma abatement, } \\
\text { catalytic destruction, thermal oxidation), aluminium production (e.g., retrofit), magnesium } \\
\text { production }\left(\mathrm{SO}_{2} \text { replacement) }\right.\end{array}$ \\
\hline & Electrical equipment & Leakage reduction, device recycle \\
\hline & Fire extinguishing & Inert gas systems, carbon dioxide systems \\
\hline
\end{tabular}

(Fig. 2). The potential is broken into several grades by generation cost. In 2005, the generation cost for solar is much higher than that for wind. The cost of solar drops over time, however, and becomes competitive with that of wind in 2050. This cost reduction derives from reductions in technology costs assumed based on IEA (2010).

The future bioenergy potential is subject to various conditions such as land use, food demand, and agricultural productivity. A number of studies have evaluated the future bioenergy potential. We compare the global technical potential of bioenergy in 2050 estimated by previous studies. The estimated bioenergy potential in 2050 ranges broadly from 0.8 to 8.8 Gtoe at the low end of the scale to
11-35 Gtoe at the high end (Fig. 3). Here we assume a worldwide bioenergy potential of 8.7 Gtoe in 2050, the low-end estimate from Smeets et al. (2007). This value is on the high side of the low-end estimates and lower than the lowest of the high-end estimates (11 Gtoe). Smeets et al. (2007) include three types of bioenergy sources, namely, bioenergy crops, agricultural and forestry residues and waste, and forest growth. Bioenergy crops include only those cultivated from surplus agricultural land gained by increasing efficiency of food production. Thus, according to Smeets et al. (2007), the bioenergy potential of 8.7 Gtoe can be supplied without sacrificing food production or expanding the area of agricultural land. Based on this 
Table 3 Summary of socioeconomic scenarios and projected service demands in major regions

\begin{tabular}{|c|c|c|c|c|c|c|c|}
\hline & World & USA & EU27 & Japan & Russia & China & India \\
\hline \multicolumn{8}{|c|}{ Population (million) } \\
\hline 2005 & 6,535 & 303 & 490 & 127 & 143 & 1,320 & 1,131 \\
\hline 2020 & 7,699 & 346 & 505 & 124 & 135 & 1,439 & 1,367 \\
\hline 2050 & 9,171 & 404 & 494 & 102 & 116 & 1,426 & 1,614 \\
\hline $\operatorname{CAGR}^{\mathrm{a}}(\%)$ & 0.76 & 0.64 & 0.02 & -0.50 & -0.46 & 0.17 & 0.79 \\
\hline \multicolumn{8}{|c|}{ GDP (trillion US\$2005) } \\
\hline 2005 & 44.9 & 12.4 & 13.7 & 4.6 & 0.8 & 2.4 & 0.8 \\
\hline 2020 & 66.1 & 16.1 & 17.2 & 5.2 & 1.3 & 6.9 & 2.1 \\
\hline 2050 & 151.1 & 28.5 & 28.4 & 6.9 & 4.4 & 21.6 & 10.9 \\
\hline $\operatorname{CAGR}^{\mathrm{a}}(\%)$ & 2.73 & 1.86 & 1.63 & 0.92 & 3.97 & 4.98 & 6.03 \\
\hline \multicolumn{8}{|c|}{ Crude steel production (million tons) } \\
\hline 2005 & 1,137 & 95 & 195 & 112 & 66 & 356 & 38 \\
\hline 2020 & 1,588 & 113 & 236 & 105 & 81 & 529 & 90 \\
\hline 2050 & 2,769 & 154 & 330 & 89 & 104 & 535 & 650 \\
\hline $\operatorname{CAGR}^{\mathrm{a}}(\%)$ & 2.00 & 1.08 & 1.17 & -0.52 & 1.01 & 0.91 & 6.51 \\
\hline \multicolumn{8}{|c|}{ Cement production (million tons) } \\
\hline 2005 & 2,305 & 100 & 254 & 69 & 49 & 1,012 & 143 \\
\hline 2020 & 3,162 & 113 & 269 & 66 & 58 & 1,175 & 395 \\
\hline 2050 & 4,518 & 131 & 273 & 52 & 59 & 1,197 & 686 \\
\hline $\operatorname{CAGR}^{\mathrm{a}}(\%)$ & 1.51 & 0.60 & 0.16 & -0.61 & 0.41 & 0.37 & 3.55 \\
\hline \multicolumn{8}{|c|}{ Passenger transport (trillion passengers-km) } \\
\hline 2005 & 27.6 & 8.1 & 5.3 & 1.3 & 0.8 & 1.9 & 1.1 \\
\hline 2020 & 35.2 & 9.2 & 6.2 & 1.3 & 1.1 & 3.0 & 1.5 \\
\hline 2050 & 74.3 & 10.7 & 7.5 & 1.1 & 2.7 & 13.2 & 5.4 \\
\hline $\mathrm{CAGR}^{\mathrm{a}}(\%)$ & 2.22 & 0.63 & 0.80 & -0.45 & 2.63 & 4.44 & 3.61 \\
\hline \multicolumn{8}{|c|}{ Freight transport (trillion tons-km) } \\
\hline 2005 & 17.1 & 4.6 & 2.2 & 0.3 & 1.5 & 2.3 & 0.7 \\
\hline 2020 & 22.0 & 5.2 & 2.7 & 0.3 & 1.7 & 3.5 & 1.1 \\
\hline 2050 & 43.8 & 6.0 & 3.7 & 0.2 & 4.4 & 9.8 & 3.6 \\
\hline $\operatorname{CAGR}^{\mathrm{a}}(\%)$ & 2.11 & 0.61 & 1.10 & -0.31 & 2.44 & 3.25 & 3.76 \\
\hline
\end{tabular}

${ }^{a}$ Growth rate is calculated using the compound annual growth rate (CAGR) between 2005 and 2050

Fig. 2 Technical potential of solar and wind worldwide
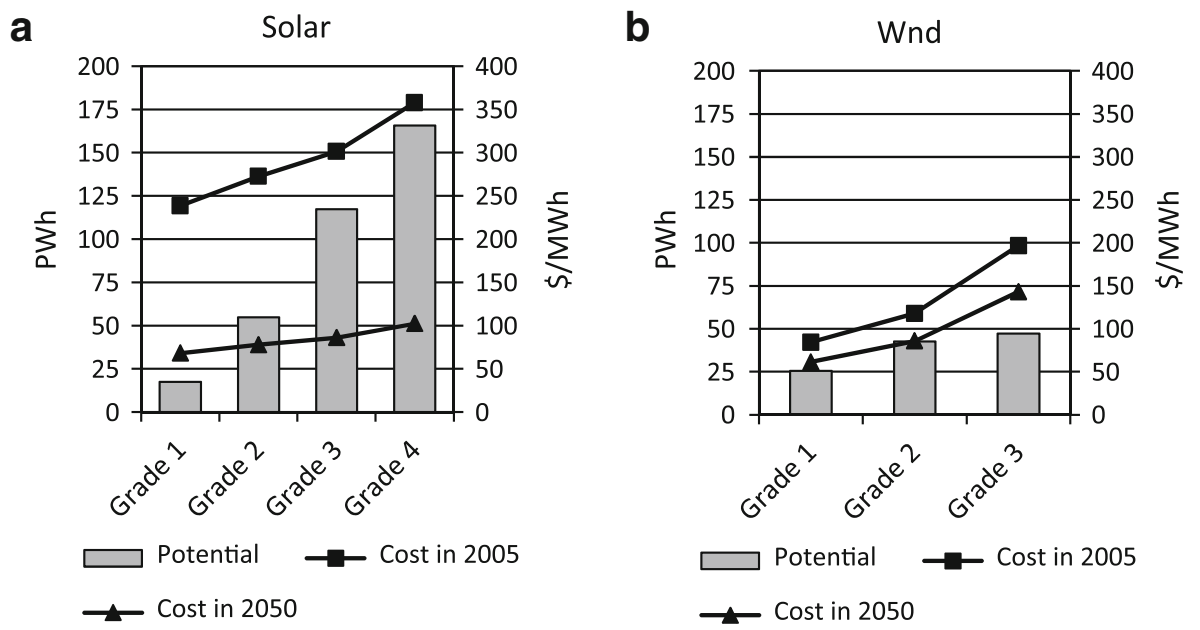


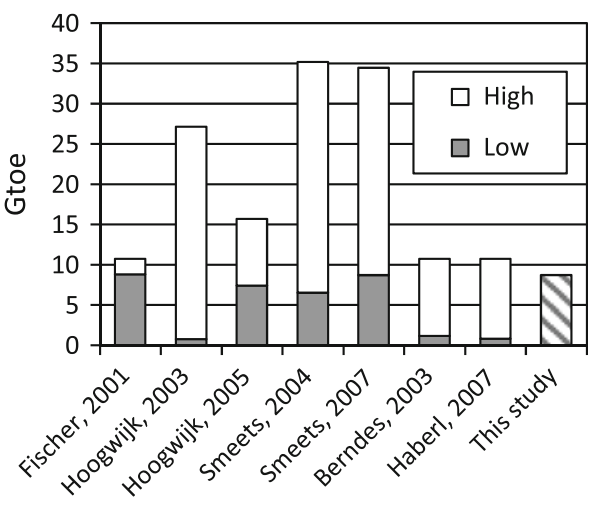

Fig. 3 Comparison of global bioenergy supply potential in 2050. Source: Fisher and Schrattenholzer (2001), Hoogwijk et al. (2003, 2005), Smeets et al. (2004, 2007), Berndes et al. (2003), Haberl et al. (2007)

information, we assume that bioenergy production of less than 8.7 Gtoe causes no major change of land use and no additional $\mathrm{CO}_{2}$ emission. ${ }^{4}$

For nuclear energy, we develop a scenario for future nuclear power capacity expansion based on existing government plans and use it for all model runs. The scenario includes new construction of nuclear power plants already under construction and nuclear power plants already planned or proposed. Information on the new construction of nuclear power plants is taken from the World Nuclear Association (http://www.world-nuclear.org/info/reactors.html). In this scenario, the global total nuclear power plant capacity increases from $364 \mathrm{GW}$ in 2005 to $846 \mathrm{GW}$ in $2050 .^{5}$

For CCS, we assume a worldwide $\mathrm{CO}_{2}$ storage capacity of about 4,600 $\mathrm{GtCO}_{2}$. This is a median of the estimated values in various studies (Dooley et al. 2006; Hendriks et al. 2004; IEA 2008, 2010). Further, we assume the maximum annual storage rate based on an ambitious growth pathway in IEA (2010). In this scenario, the maximum annual $\mathrm{CO}_{2}$ storage worldwide in 2050 is about $10 \mathrm{GtCO}_{2}$.

\section{GHG price paths}

To understand the relationship between GHG emission reduction and the emission reduction cost, we perform

\footnotetext{
4 This is a rough approximation of the relationship between bioenergy supply and $\mathrm{CO}_{2}$ emission from land use change. More detailed analysis on bioenergy utilization and $\mathrm{CO}_{2}$ emission requires an integrated modeling approach on energy and land use. Yet this type of analysis remains to be done.

5 The nuclear power plant accident in Fukushima may increase scepticism about the safety of nuclear power plants and persuade some countries to scale down their nuclear policies. Some countries, in fact, have already announced plans to phase out their nuclear plants. Overall, however, the impact of the Fukushima nuclear accident over long-term nuclear policies around the world remains to be seen. Therefore, this impact is not considered in this study.
}

multiple model runs with different GHG price paths and compare the resulting emissions. Figure 4 shows $13 \mathrm{GHG}$ price path scenarios run through the model.

The scenario names are based on the GHG price in 2050 (in the $\mathrm{s} 800$ scenario, for example, the GHG price in 2050 is $\$ 800 / \mathrm{tCO}_{2}$-eq). In all of the scenarios except the s0 scenario, the GHG price starts from $\$ 0 / \mathrm{tCO}_{2}$-eq in 2010 and increases linearly up to 2050 (the price in the $\mathrm{s} 0$ scenario stays at zero). The plot therefore shows, for example, a GHG price of \$200/ $\mathrm{tCO}_{2}$-eq in the year 2020 in s800 scenario.

\section{Reference scenario}

The s0 scenario can be regarded as the 'no climate policy' case, as it lacks any incentive to reduce GHG emissions specifically for climate mitigation. Accordingly, we use the s0 scenario as the basis for emission reduction. For convenience, we refer to the s0 scenario as the 'reference scenario' in the sections to follow.

Global GHG emissions in the reference scenario reach 52 $\mathrm{GtCO}_{2}$-eq in 2020 and $70 \mathrm{GtCO}_{2}$-eq in 2050 . These levels correspond to a 37 and $85 \%$ increase relative to the 1990 level, respectively (Fig. 5). GHG emissions increase more rapidly in non-Annex I regions than in Annex I regions: the average growth rate for GHG emissions from 1990 to 2050 in the former is $1.5 \% / y e a r$, while that in the latter is only $0.3 \% / y e a r$. As a consequence, the share of GHG emissions from non-Annex I regions increases from $49 \%$ in 1990 to $60 \%$ in 2020 and to $65 \%$ in 2050. The share of GHG emissions from Asian regions, that is, from Japan, China, India, and 'Other Asia,' also changes remarkably, rising from only $25 \%$ in 1990 to about $40 \%$ in 2020 . By country, the GHG emissions grow fast in China and India, reaching 4- and 4.5-fold the 2005 levels by 2050, respectively.

\section{Achievability of the target and required GHG emission reduction}

In this section we ask two questions: "Will it be technically possible to achieve a $50 \%$ reduction of GHG emissions by 2050 relative to the 1990 level?" and if so, "What emission reduction will be required in major countries in the midand long-term?" We address these questions using marginal abatement cost (MAC) curves.

\section{Developing the MAC curves}

A MAC curve depicts the relationship between the MAC and emission reduction in a region and year in question. To develop MAC curves here, we use the simulation results of GHG price path scenarios in which GHG emissions are 
estimated along an externally fixed GHG emission price path. The GHG emission price in these price scenarios is theoretically equal to a MAC of GHG emission. Hence, we develop the MAC curves using the relationship between the GHG emission price and GHG emission reduction in
GHG price path scenarios relative to the reference scenario. Note that GHG emission trading among the regions does not take place in GHG price path scenarios. Therefore, the MAC curves developed in this study represent the relationship between the MAC and GHG emission reduction
Fig. 4 GHG price path scenarios

Fig. 5 GHG emissions in the reference scenario. Note GHG emissions are calculated as the weighted sum of $\mathrm{CO}_{2}, \mathrm{CH}_{4}$, $\mathrm{N}_{2} \mathrm{O}, \mathrm{HFC}$, PFC, and $\mathrm{SF}_{6}$, using the 100-year Global Warming Potentials. Emissions from 1990 to 2005 are calculated using the EDGAR v4.1 emission database (European Commission et al. 2010)
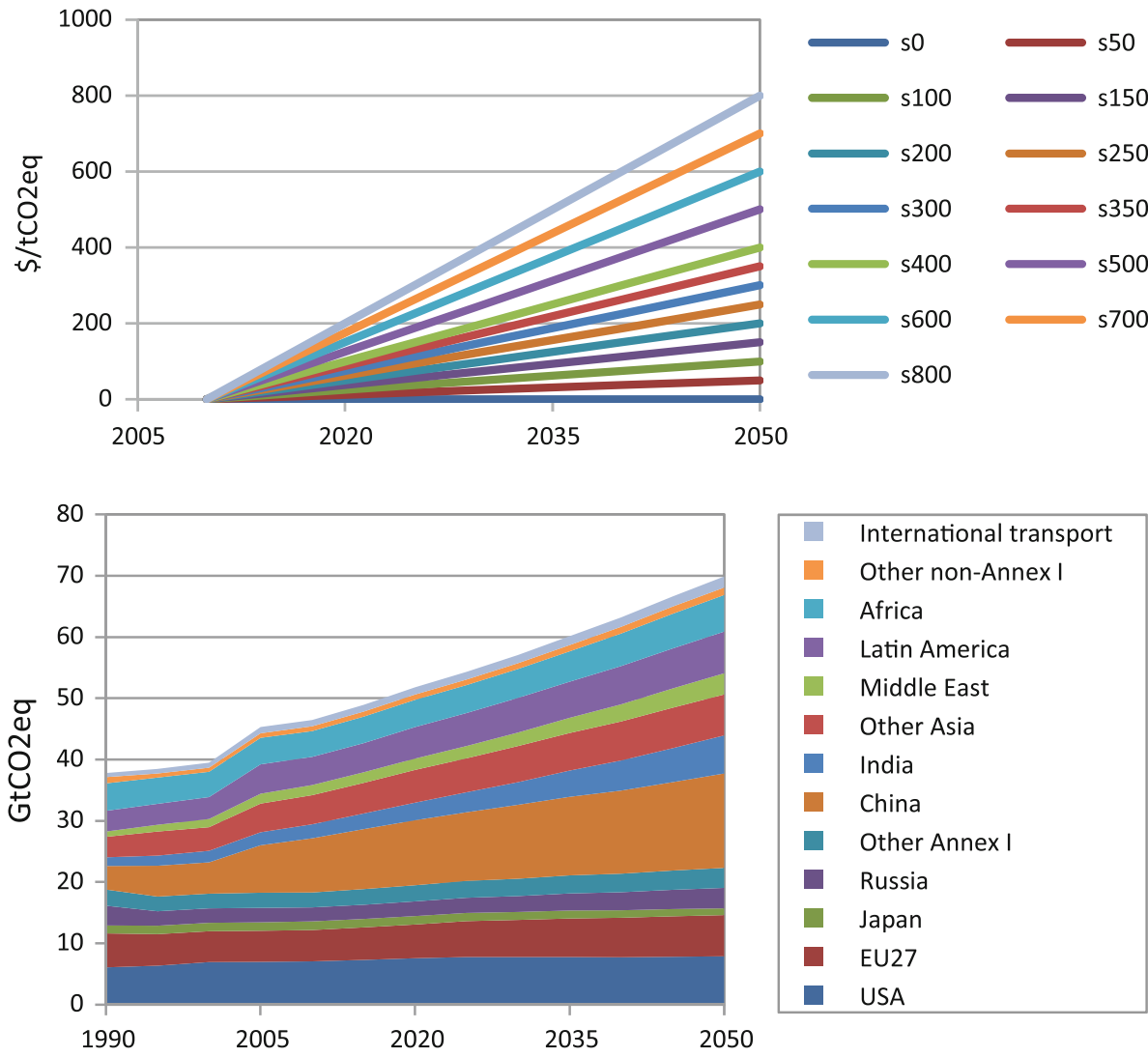

\begin{tabular}{|l|}
\hline International transport \\
Other non-Annex I \\
Africa \\
Latin America \\
Middle East \\
Other Asia \\
India \\
China \\
Other Annex I \\
Russia \\
Japan \\
EU27 \\
USA \\
\hline
\end{tabular}

b

C
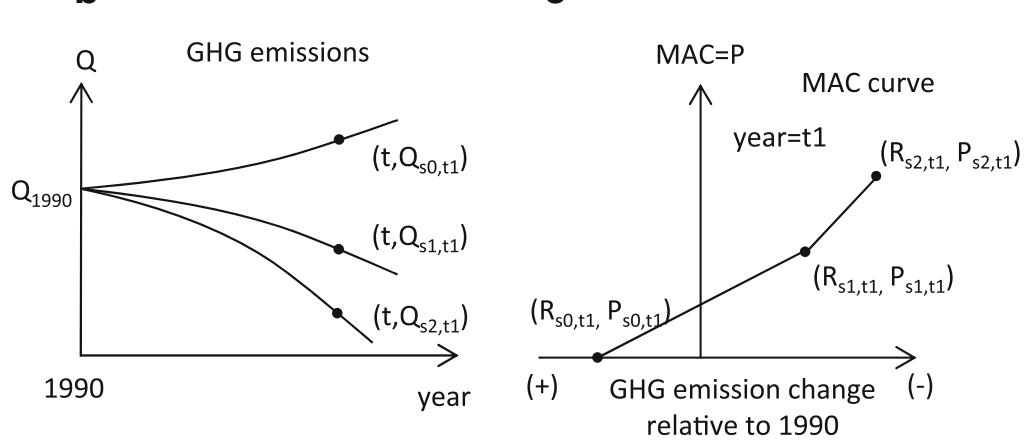

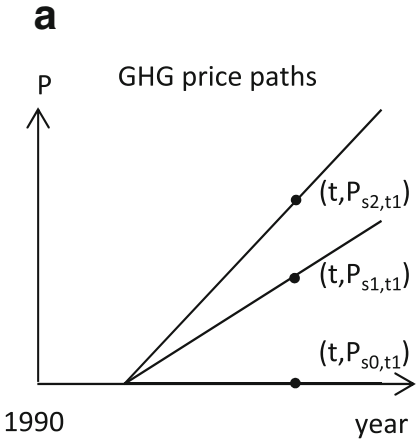

\footnotetext{
$\mathrm{t}$ : year

$\mathrm{s}$ : GHG price scenario

$P_{s, t}: G H G$ price in scenario $s$ and year $t$

$\mathrm{Q}_{\mathrm{s}, \mathrm{t}}$ : $\mathrm{GHG}$ emissions in scenario $\mathrm{s}$ and year $\mathrm{t}$

$\mathrm{Q}_{1990}$ : GHG emissions in 1990

$R_{s, t}: G H G$ emissions change relative to 1990 in scenario $s$ and year $t$

$\mathrm{R}_{\mathrm{s}, \mathrm{t}}=\left(\mathrm{Q}_{\mathrm{s}, \mathrm{t}}-\mathrm{Q}_{1990}\right) / \mathrm{Q}_{1990} \times 100$
}

Fig. 6 Methodology for developing MAC curves in this study 
Fig. 7 Estimated MAC curves for major regions in 2020 and 2050. The horizontal axis indicates the rate of GHG emission change relative to 1990. A negative value denotes a reduction and a positive value denotes an increase relative to 1990
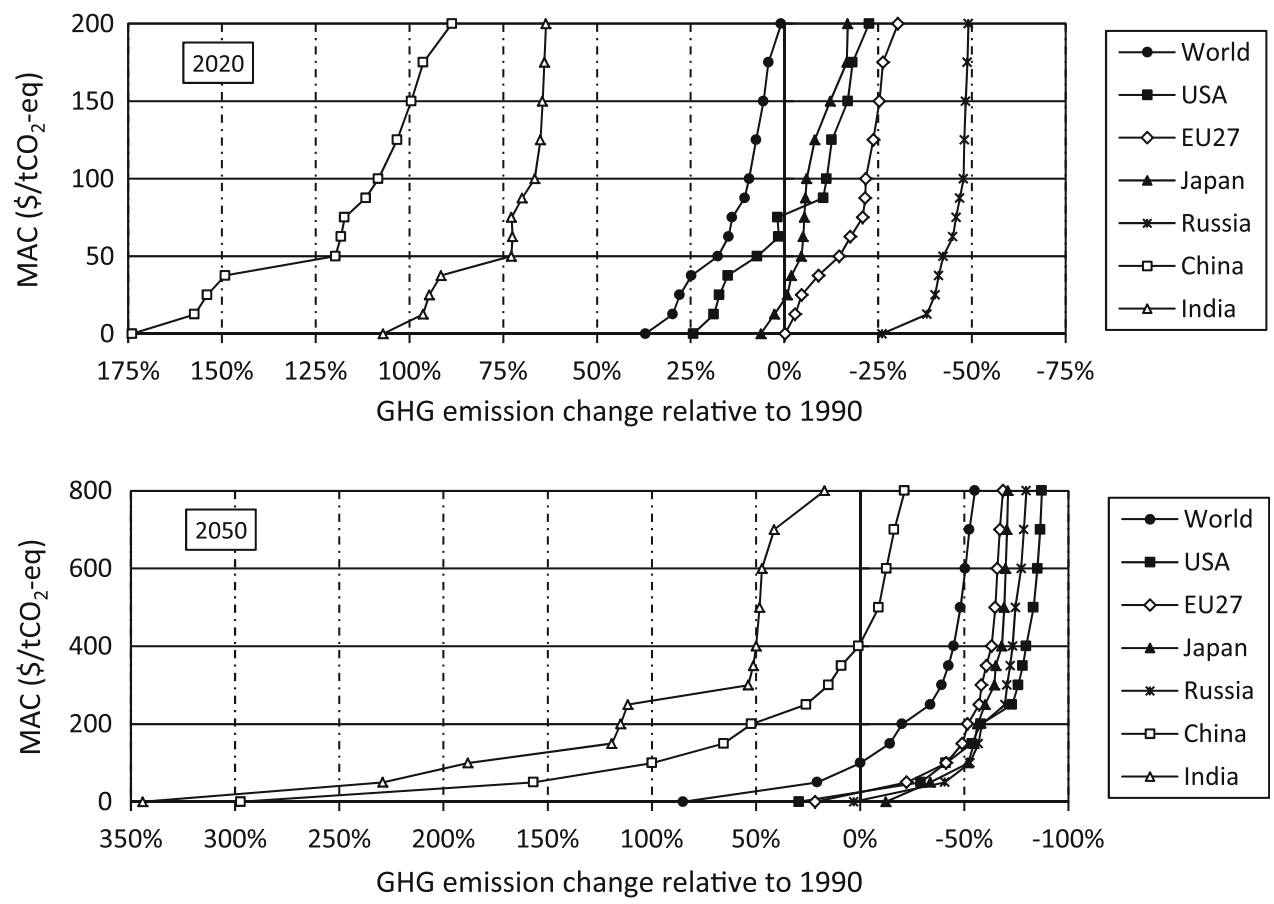

within the region. Figure 6 illustrates how the MAC curves are developed for this study.

MAC curves are developed in two steps: (1) simulate GHG emissions in each GHG price path scenario (see Fig. 6b), (2) draw the MAC curve by plotting GHG emission change rates $(R)$ and the corresponding carbon prices $(P)$ (see Fig. 6c).

Analysis using MAC curves

Figure 7 shows MAC curves estimated for six major regions and the world in 2020 and 2050.

The MAC curve for each region can be characterized by the $x$-intercept and slope of the curve. The $x$-intercept represents the GHG emission change rate relative to 1990 in the reference scenario, in which the GHG price is $\$ 0$ / $\mathrm{tCO}_{2}$-eq. The slope of the curve represents the sensitiveness of GHG emissions to the MAC: the milder the slope, the larger the GHG emission reduction when the MAC increases.

In 2050, MAC curves for China and India have very high $x$-intercepts and remarkably mild slopes, especially in the lower MAC range. This shows that, in spite of the significant increase in GHG emissions in 2050 relative to 1990 in the reference scenario, there are huge GHG emissions reduction potentials in China and India in the lower range of cost. Among the industrialized regions, the MAC curve for the USA has the mildest slope. At the cost of $\$ 800 / \mathrm{tCO}_{2}$-eq, the reduction rate relative to 1990 reaches about $90 \%$ in the USA, whereas those of EU27 and Japan reach about $70 \%$. The variance of the reduction rate among different regions stems from differences in the reference emissions, technology performance and availability (including renewable energy, CCS), energy and non-energy service demand structures, energy price, etc.

Figure 7 indicates that the GHG emission reduction target of $50 \%$ relative to 1990 is achievable at a marginal cost of $\$ 600 / \mathrm{tCO}_{2}$-eq. If we assume the same MAC- $\$ 600 /$ $\mathrm{tCO}_{2}$-eq-across the world, GHG emissions in 2050 end up at $-85 \%$ in the USA, $-66 \%$ in the EU, $-70 \%$ in Japan, $-13 \%$ in China, and $+47 \%$ in India, compared to the 1990 level. Next, we want to determine which emission reductions in 2020 are consistent with the 2050 target. According to the GHG price path scenarios, the GHG price of $\$ 150 /$ $\mathrm{tCO}_{2}$-eq in 2020 corresponds to the GHG price of $\$ 600 /$ $\mathrm{tCO}_{2}$-eq in 2050 (see Fig. 4). Therefore, the reduction rate at $\$ 150 / \mathrm{tCO}_{2}$-eq in 2020 is consistent with the 2050 target. At $\$ 150 / \mathrm{tCO}_{2}$-eq, global GHG emissions increase by $6 \%$ in 2020 relative to the 1990 level. The changes of regional GHG emissions at $\$ 150 / \mathrm{tCO}_{2}$-eq in 2020 relative to 1990 differ significantly among regions: $-17 \%$ in the USA, $-25 \%$ in the EU27, $-12 \%$ in Japan, $+99 \%$ in China, and $+65 \%$ in India. Note that these values include only domestic GHG emissions and do not include carbon credit, which is traded internationally. Thus, the values do not correspond directly to regional emission targets, as the emission targets might include carbon credit. 
Transition scenario for achieving a $50 \%$ reduction by 2050

In this section we present the s600 scenario in which $\mathrm{GHG}$ emissions in 2050 are reduced by $50 \%$ relative to the 1990

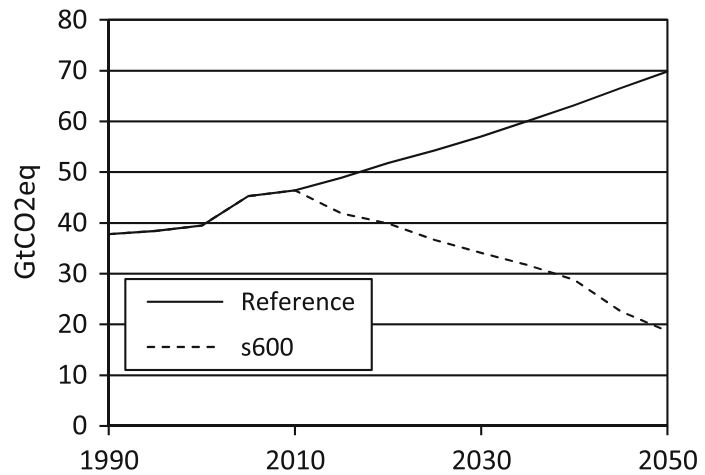

Fig. 8 Global GHG emissions in the reference and the s600 scenarios

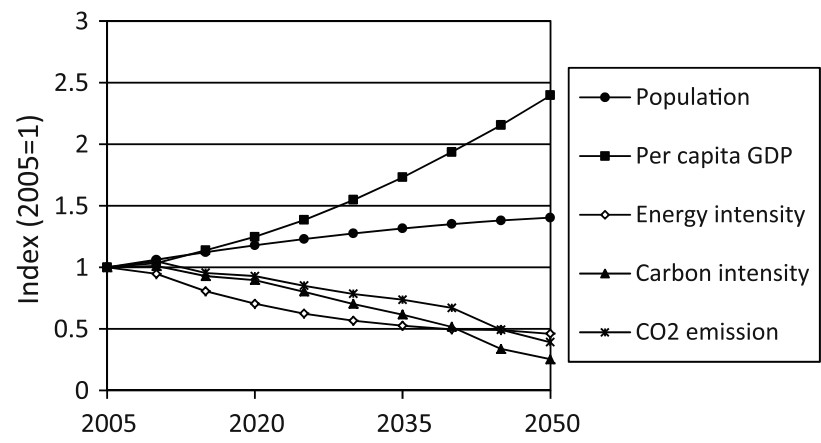

Fig. 9 Decomposition of global $\mathrm{CO}_{2}$ emissions change in the 5600 scenario level, with a focus on dynamic changes in global GHG emissions and energy systems.

\section{GHG emission path}

In the s600 scenario, global GHG emissions become 40 $\mathrm{GtCO}_{2}$-eq in 2020 and $19 \mathrm{GtCO}_{2}$-eq in 2050 , values that correspond to +6 and $-50 \%$ of the 1990 levels, respectively (Fig. 8). Compared to the reference scenario, a significant GHG emission reduction is required in the s600 scenario: the rates of $\mathrm{GHG}$ emission reduction from the reference scenario are $23 \%$ in 2020 and $73 \%$ in 2050. The average annual rate of $\mathrm{GHG}$ emission reduction from 2005 to 2050 in the s600 scenario is $1.9 \%$.

A decomposition analysis will help us understand, from a macroscopic viewpoint, how that rapid emission reduction is achieved in the s600 scenario. This method is based on the Kaya identity (Yamaji et al. 1991). The approach begins with an identity in which $\mathrm{CO}_{2}$ emissions from fossil fuel combustion can be expressed as the product of four terms, as follows:

$\mathrm{CO}_{2}=\left(\mathrm{CO}_{2} / \mathrm{PE}\right) \times(\mathrm{PE} / \mathrm{GDP}) \times(\mathrm{GDP} / \mathrm{POP}) \times \mathrm{POP}$

where $\mathrm{CO}_{2}$ is $\mathrm{CO}_{2}$ emission, $\mathrm{PE}$ is primary energy consumption, GDP is gross domestic product, and POP is population. The term $\mathrm{CO}_{2} / \mathrm{PE}$ represents average carbon intensity of energy, $\mathrm{PE} / \mathrm{GDP}$ represents economy-wide energy intensity, and GDP/POP represents average per capita GDP.

Figure 9 shows the result of the decomposition.

Population and per capita GDP are the increasing factors. Per capita GDP increases rapidly, reaching 2.4-fold
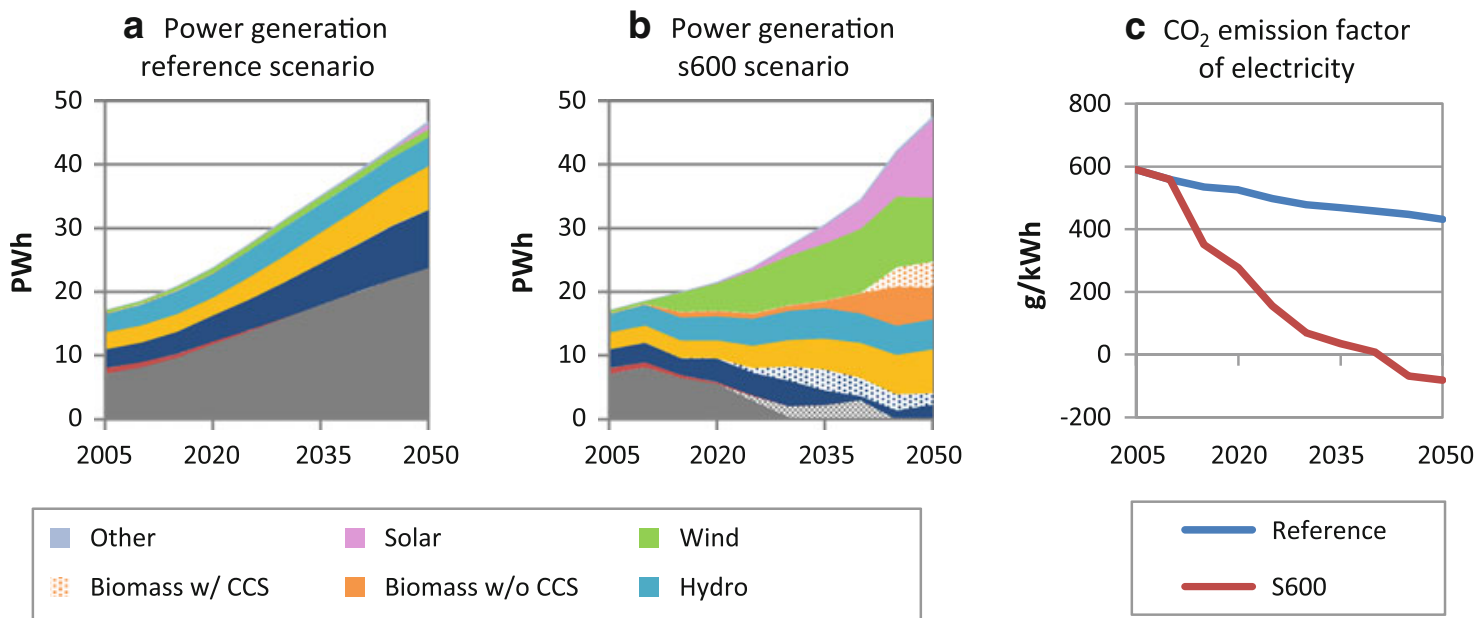

\begin{tabular}{|c|c|c|c|c|c|}
\hline$\square$ & Other & $\square$ & Solar & $\square$ & Wind \\
\hline is & Biomass w/ CCS & $\square$ & Biomass w/o CCS & $\square$ & Hydro \\
\hline$\square$ & Nuclear & : & Gas w/ CCS & $\square$ & Gas w/o CCS \\
\hline : & Oil w CCS & $\square$ & Oil w/o CCS & 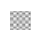 & Coal w/ CCS \\
\hline$\square$ & Coal w/o CCS & & & & \\
\hline
\end{tabular}

Fig. 10 Transition in the power generation sector. The $\mathrm{CO}_{2}$ emission factor of electricity denotes the $\mathrm{CO}_{2}$ emission per unit of electricity generation 
the 2005 level by 2050. In spite of the increasing population and per capita GDP, $\mathrm{CO}_{2}$ emissions decrease because of significant reductions of energy intensity and carbon intensity. Energy intensity is the fastest-declining factor in the coming 3 decades and halves by 2040 . Carbon intensity plays a somewhat smaller role than energy intensity in reducing $\mathrm{CO}_{2}$ in the near future. As time passes, however, it plays an increasingly important role, eventually overtaking energy intensity after 2040. By 2050, carbon intensity drops to one-fourth of the 2005 level.
Energy system transitions

This section interprets sectoral results to help us better understand the energy system transitions in a scenario where the targeted $50 \%$ reduction of GHG emissions by 2050 is achieved.

\section{Power generation}

In the reference scenario, global power generation increases from 17 to $47 \mathrm{PWh}$ over the period from 2005 to 2050
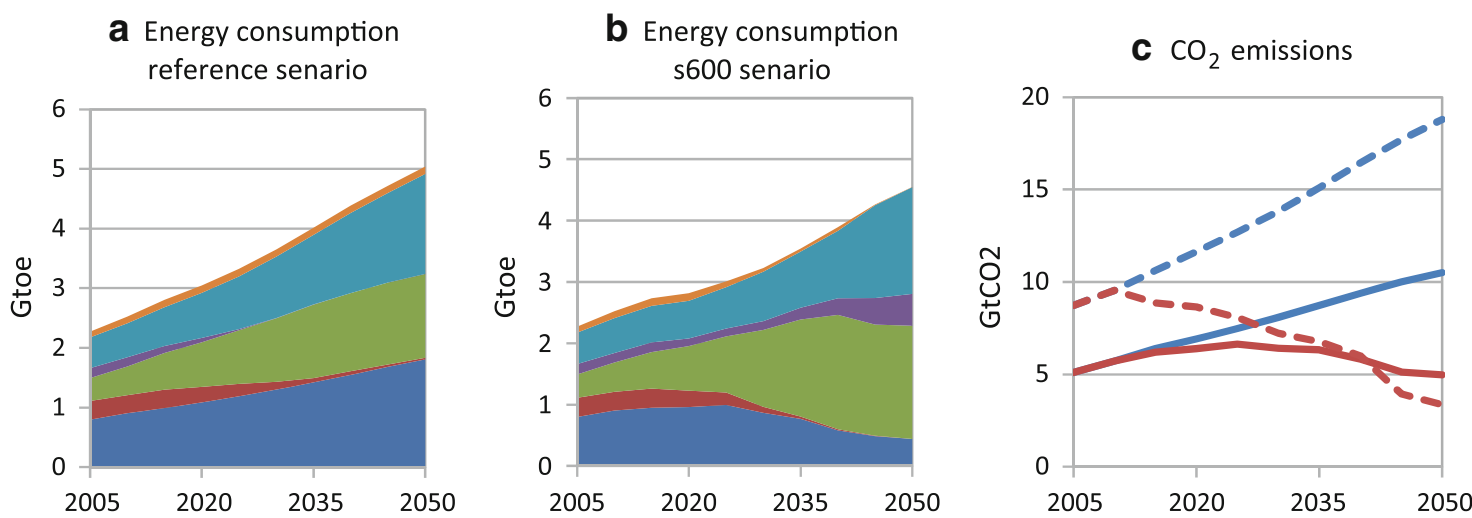

Heat Electricity Biomass Gas Oil Coal

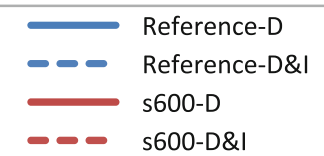

Fig. 11 Transition in the industrial sector. $D$ in $\mathbf{c}$ on the right denotes direct emission; $D \& I$ denotes the sum of direct emission and indirect emission

Fig. 12 Technological changes in passenger cars a Passenger car technologies reference scenario

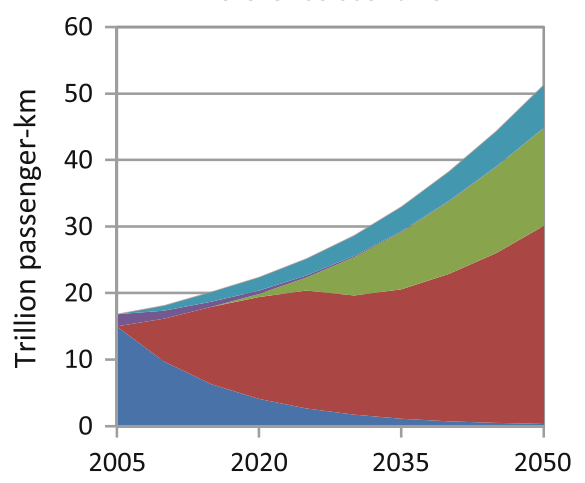

b Passenger car technologies s600 scenario

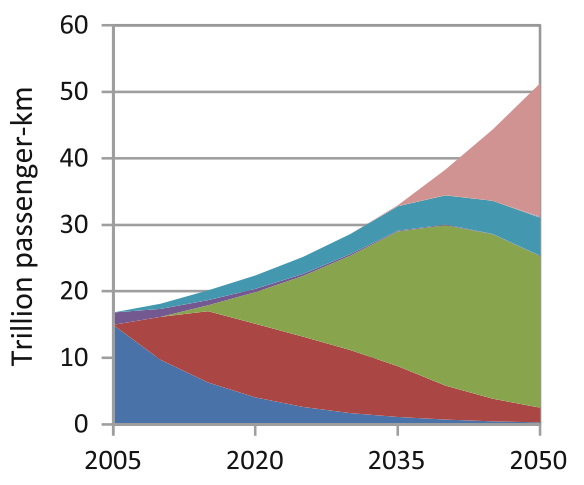

\begin{tabular}{|c|c|c|}
\hline Gasoline ICEV-Cnv & Gasoline ICEV-Eff & Gasoline HEV \\
\hline Diesel ICEV-Cnv & Diesel ICEV-Eff & Diesel HEV \\
\hline EV & FCV & \\
\hline
\end{tabular}


(Fig. 10). The energy source composition changes moderately in the reference scenario over the same period. The share of coal, for example, increases from 42 to $51 \%$. The $\mathrm{CO}_{2}$ emission factor of electricity, namely, $\mathrm{CO}_{2}$ emission per unit of electricity generation, decreases gradually over time, thanks mainly to improved generation efficiency in thermal power plants.

In contrast to the reference scenario, power generation technologies drastically change in the s600 scenario. Coal power generation, the largest contributor to $\mathrm{CO}_{2}$ emission in 2005, contributes progressively less in s600 as time passes, and CCS is introduced after 2020. The deployment of renewable energy accelerates over the same period: wind accelerates after 2010; solar and biomass accelerate after 2020 and 2030, respectively. Thus, the share of renewables dramatically increases over time: by 2050, wind, solar, biomass, and hydro together account for about $75 \%$ of the total power generation. The introduction of bioenergy in combination with $\mathrm{CCS},{ }^{6}$ a power generation technology with a net negative emission, in 2040, confers a significant effect, resulting in a net negative $\mathrm{CO}_{2}$ emission factor from that point forward.

\section{Industry}

In the reference scenario, energy consumption in the industrial sector in 2050 reaches 2.2-fold the level of 2005 (Fig. 11). The shares of gas and electricity increase in the fuel mix. As a consequence of this increase in energy consumption and change in the fuel mix, direct $\mathrm{CO}_{2}$ emissions in 2050 reach 2.1-fold the level of 2005.

The s600 scenario diverges from the reference case in energy saving and through a fuel switch. The change in energy saving in s600 is derived from reduced fuel consumption: in 2050, energy consumption is reduced by $10 \%$ from the reference case. The fuel shift in the s600 scenario is a large shift from coal to gas. The share of coal declines from 35 to $10 \%$ from 2005 to 2050 , while that of gas rises from 17 to $41 \%$. As a consequence of this energy saving and fuel switch, direct emissions of $\mathrm{CO}_{2}$ in 2050 are reduced by half from the reference scenario, ending up, in 2050, at about the same level as 2005. Moreover, if indirect

\footnotetext{
${ }^{6}$ AIM/Enduse[Global] includes integrated biomass gasification combined cycle (biomass IGCC) with CCS as an option for power generation. Biomass IGCC is a promising biomass power generation technology considered both highly efficient and economically feasible, as it is technically similar to the efficient coal IGCC process and can profit from the experiences gained with coal IGCC plants (Rhodes 2007). When biomass IGCC and CCS are integrated in a combined system, nearly all $\mathrm{CO}_{2}$ can be captured (Luckow et al. 2010). Yet biomass IGCC is still in the demonstration phases: only a few demonstration plants have been built so far.
}

$\mathrm{CO}_{2}$ emissions by electricity use are included, the significantly improved $\mathrm{CO}_{2}$ emission factor of electricity in the s600 scenario (see Fig. 10c) substantially reduces the $\mathrm{CO}_{2}$ emissions from the reference level. $\mathrm{CO}_{2}$ emissions in 2050 are reduced by $82 \%$ from the reference scenario and by $62 \%$ from the 2005 level, if indirect $\mathrm{CO}_{2}$ emissions are included.

\section{Transport}

Considerable technological changes take place in the transport sector. Figure 12 shows the technological change in passenger cars. In the reference scenario, the efficient internal combustion engine vehicle (ICEV) becomes widespread. The hybrid electric vehicle (HEV) appears about 15 years into the scenario, from 2020, and steadily grows in prominence until 2050, when its share of total vehicles reaches $30 \%$.

The technological transition in the s600 scenario is more significant than that in the reference scenario. $\mathrm{HEV}$ is introduced on a large scale after 2015, and its share reaches more than $60 \%$ by 2035. The fuel cell vehicle (FCV) is rapidly deployed after 2035, and its share reaches about $45 \%$ in 2050.

As a consequence of the technological changes in the s600 scenario, the total energy consumption of the transport sector is reduced by $25 \%$ from that in the reference scenario in 2050 (Fig. 13). The widespread use of biofuel in s600 also contributes to reduced oil consumption: oil consumption falls by about $20 \%$ by 2050 relative to 2005 . This, in turn, results in a significant $\mathrm{CO}_{2}$ emission reduction in the s600 scenario: direct $\mathrm{CO}_{2}$ emission in 2050 is $60 \%$ lower than that in the reference scenario and $17 \%$ lower than the 2005 level. Moreover, if indirect emission is included, $\mathrm{CO}_{2}$ emission in 2050 is reduced by half relative to 2005. The negative emission factor of hydrogen, which is produced from biomass in combination with CCS, contributes largely to the reduction of indirect $\mathrm{CO}_{2}$ emissions.

\section{Buildings}

In the reference scenario, energy consumption in residential and commercial buildings increases by about $60 \%$ by 2050 relative to 2005 (Fig. 14). The energy mix changes considerably over time in the reference scenario, with a marked decrease of biomass and marked increase of electricity. Biomass accounts for about $30 \%$ of total energy use in buildings in 2005, most of which is traditional biomass use in the residential sector. Traditional biomass use declines over time in the reference scenario: by 2050, it accounts for only $7 \%$ of total energy consumption. In contrast to biomass, the consumption of modern forms of energy such as LPG, city gas, and electricity increases. The 

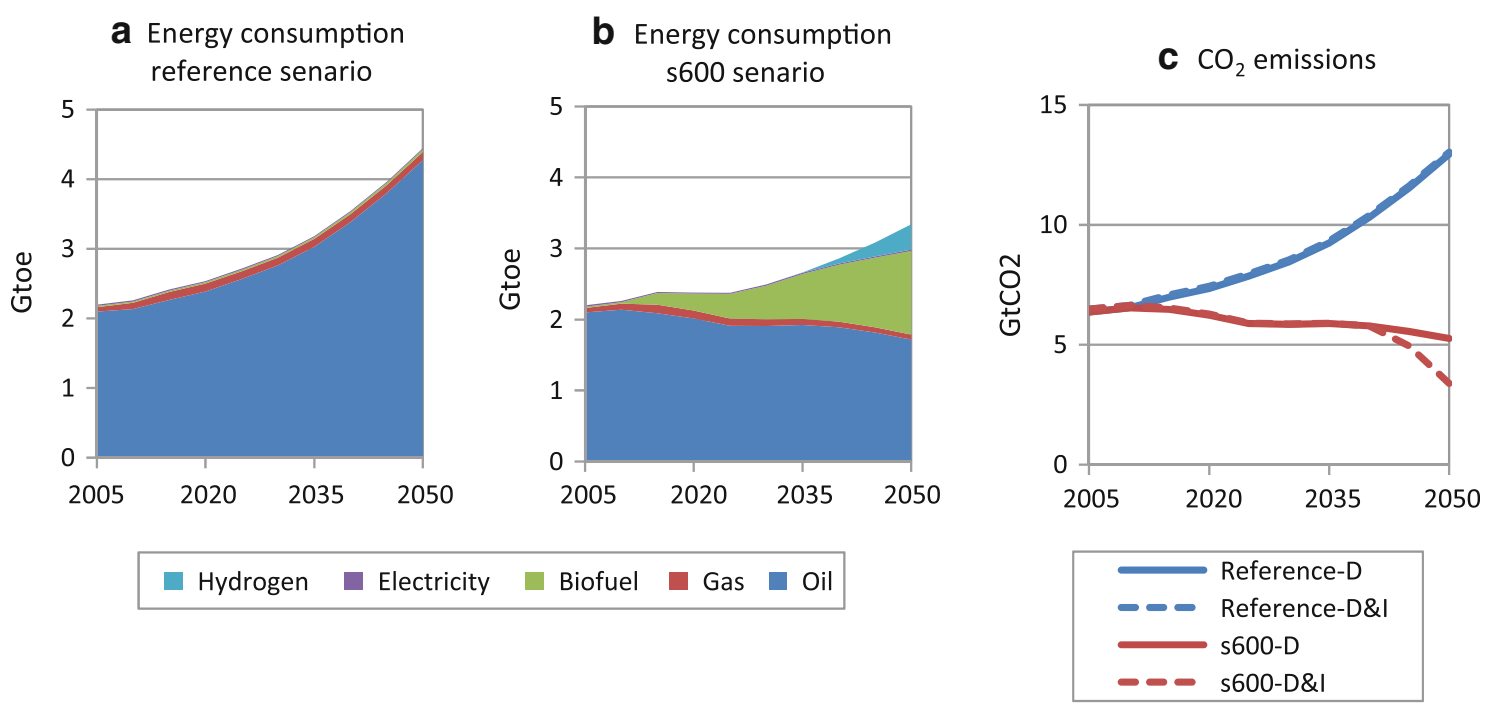

Fig. 13 Transition in the transport sector. $D$ in $\mathbf{c}$ on the right denotes direct emission; $D \& I$ denotes the sum of direct emission and indirect emission
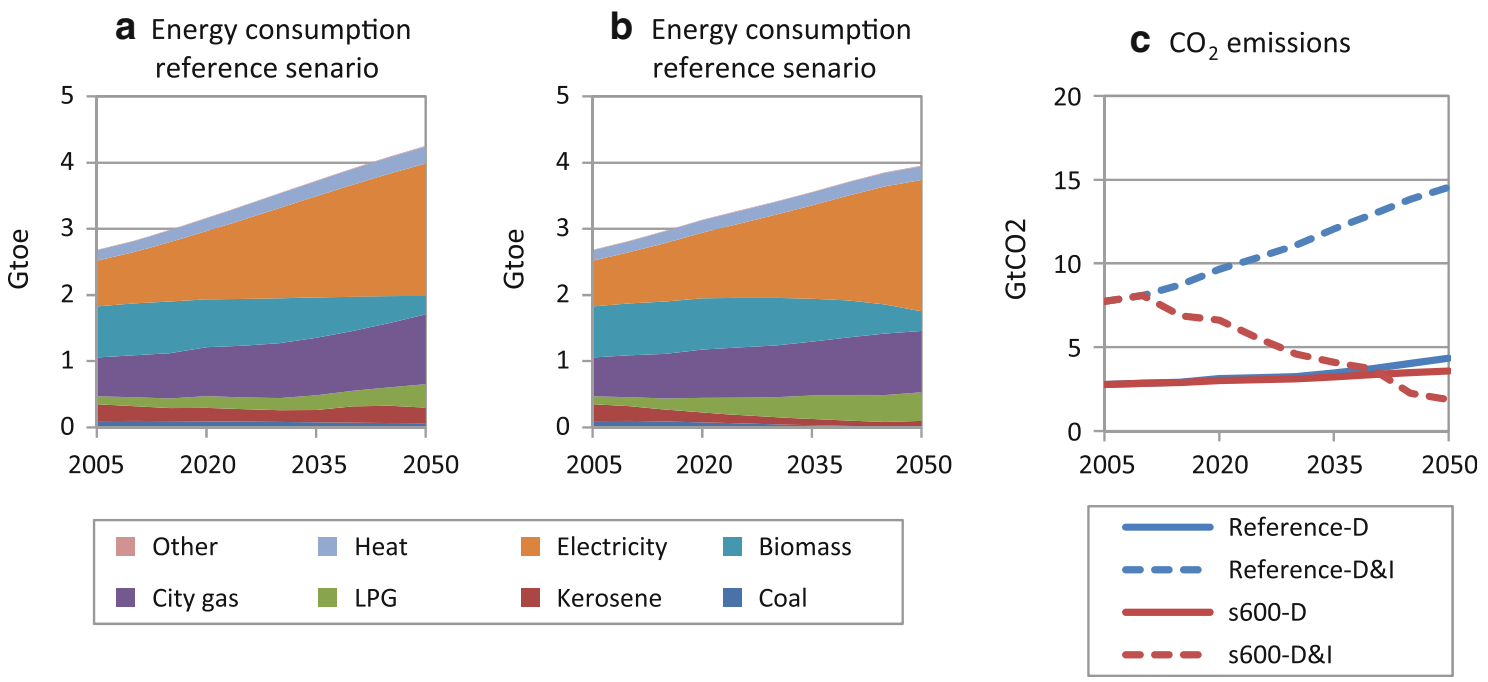

Fig. 14 Transition in the buildings sector. $D$ in $\mathbf{c}$ on the right denotes direct emission; $D \& I$ denotes the sum of direct emission and indirect emission

increase in electricity consumption is the most conspicuous: from 2005 to 2050 , the share of electricity in total energy consumption rises from 26 to $47 \%$. The increased energy consumption, in combination with the fuel mix change, pushes up $\mathrm{CO}_{2}$ emissions substantially in the reference scenario. If indirect emission is included, $\mathrm{CO}_{2}$ emissions in 2050 increase by $88 \%$ relative to 2005 .

Energy consumption in the s600 scenario shows no significant divergence from that in the reference scenario, but the drastic improvement in the $\mathrm{CO}_{2}$ emission factor of electricity in the 5600 scenario brings about a substantial reduction of $\mathrm{CO}_{2}$ emissions (a $75 \%$ reduction relative to 2005) when indirect emissions are included.

\section{Technologies for achieving $50 \%$ reduction}

The "Energy system transitions" section described energy system changes in a scenario where the targeted $50 \%$ reduction of GHG emissions by 2050 is achieved. This section gives a more detailed assessment of the respective contributions of technologies to the GHG reductions in 2020 and 2050.

In the s600 scenario, GHG emissions must be reduced by $12 \mathrm{GtCO}_{2}$-eq and $51 \mathrm{GtCO}_{2}$-eq in 2020 and 2050 , respectively, relative to the reference scenario. Figure 15 shows the contributions of various technologies to GHG reduction in 2020 and 2050. 
Fig. 15 Contributions of technologies to GHG emission reduction in 2020 and 2050 in the 5600 scenario

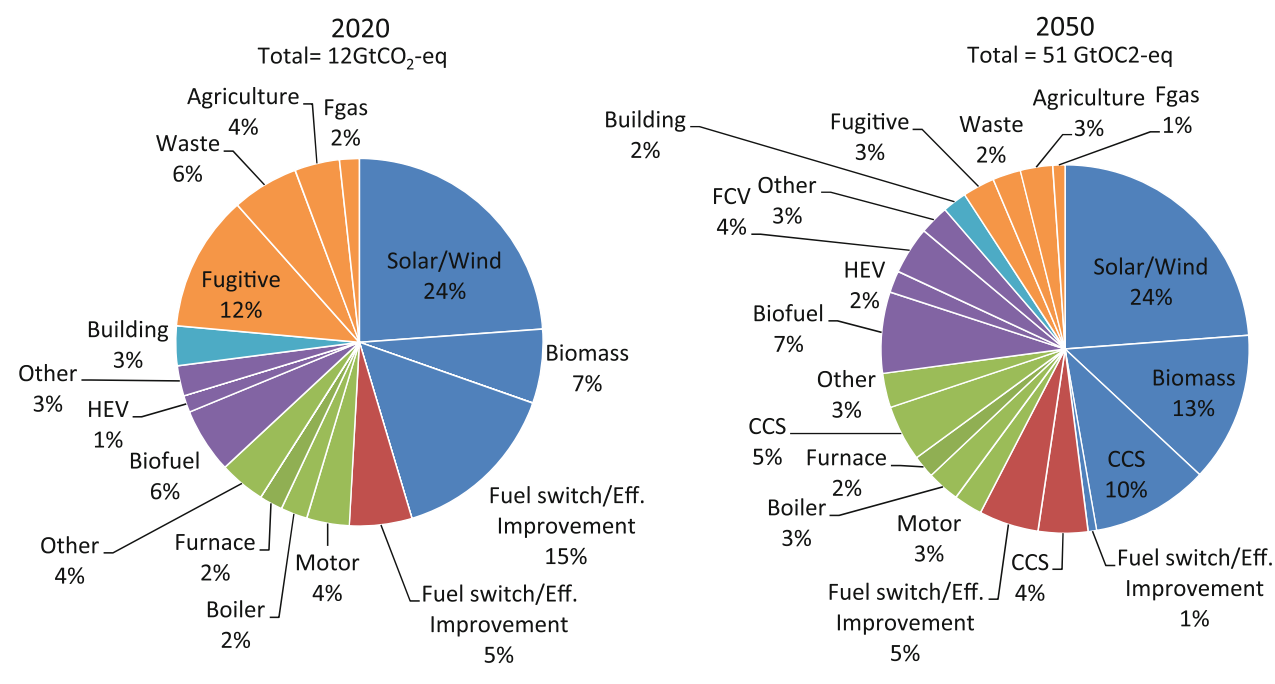

Power generation
In 2020 , the power generation sector contributes the most to GHG emission reduction, accounting for $45 \%$ of the total reduction achieved. The renewable energies, namely, solar, wind, and biomass, play a big role, together accounting for $31 \%$ of the total GHG emission reduction. The remaining reduction in the power sector mainly comes from fuel switching and efficiency improvement in thermal power generation. The industrial sector accounts for $12 \%$ of the total GHG reduction in 2020. Among the technologies in the industrial sector, efficient industrial motors make a relatively high contribution to GHG reduction. The transport sector accounts for $10 \%$ of the total GHG emission reduction in 2020. Biofuel contributes the largest reduction in the transport sector. The other reductions in the transport sector are attained from the introduction of the HEV and fuel efficiency improvement of conventional passenger vehicles, trucks, and other transport modes.

Non-energy technologies contribute substantially. In 2020 , for example, they account for as much as one-fourth of the total GHG emission reduction. Among the nonenergy technologies, systems to control fugitive $\mathrm{CH}_{4}$ emissions, including systems for gas recovery and utilization, contribute a substantial part of the 2020 reductions. Meanwhile, the waste management and agriculture sectors, respectively, contribute up to 6 and $4 \%$ of the total GHG emission reduction in 2020.

In contrast to 2020 , non-energy technologies in 2050 contribute less than $10 \%$ of the total GHG reduction. In other words, more than $90 \%$ of the total GHG reduction in 2050 is attained from energy technologies. Among the energy technologies, CCS contributes substantially. CCS systems are installed in power plants, other transformation processes, and energy-intensive industries such as iron and steel and cement. In total, CCS contributes about 100
$\mathrm{GtCO}_{2}$-eq of the GHG emission reduction, or about $20 \%$ of the total reduction, in 2050. Solar power generation, wind power generation, biomass power generation, and biofuel also contribute substantially to the GHG emission reduction. In 2050, for example, they collectively account for $44 \%$ of the total reduction.

\section{Technological cost of achieving a $50 \%$ reduction}

A $50 \%$ reduction of GHG emissions by 2050 can be achieved by introducing the technologies described in "Technologies for achieving $50 \%$ reduction." Yet introducing GHG emission reduction technologies also requires additional cost. Our next task, therefore, is to determine cost for introducing emission reduction technologies in different regions and sectors. In this section we assess the additional investment and total technological cost to achieve the s600 scenario.

\section{Investment cost}

In the s600 scenario, worldwide cumulative incremental investment reaches US\$ 6.0 trillion by 2020 and US\$ 73 trillion by 2050 relative to the reference scenario. These amounts correspond to 0.7 and $1.8 \%$ of world GDP in the same periods.

Figure 16 shows a regional breakdown of required incremental investment cost in the 5600 scenario relative to the reference scenario by 2020 and 2050. By 2020, Annex I regions account for about half of total world investment, and non-Annex I regions account for $46 \%$. Yet by 2050, the share of non-Annex I regions in world investment rises to $55 \%$. By country, the USA and China together account 
Fig. 16 Regional breakdown of cumulative incremental investment cost in the s600 scenario by 2020 and 2050 relative to the reference scenario
2020

Total $=6.0$ trillion 2005US\$

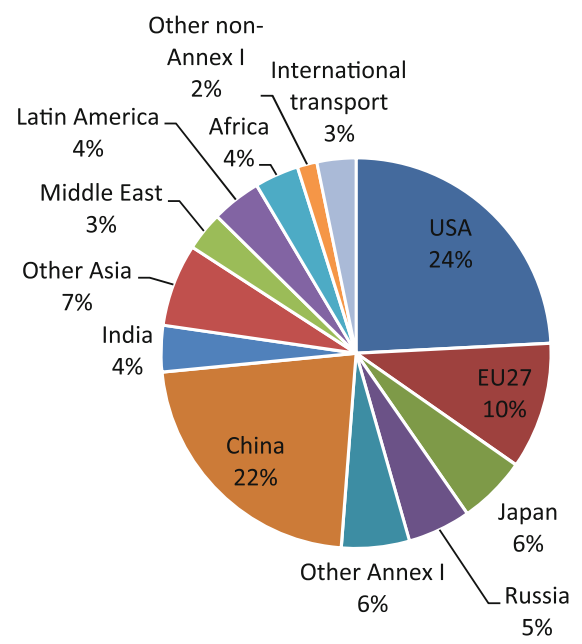

2020

Total $=6.0$ trillion 2005US\$

cumulative incremental investment cost in the $s 600$ scenario by 2020 and 2050 relative to the reference scenario
2050

Total= 73trillion 2005US\$

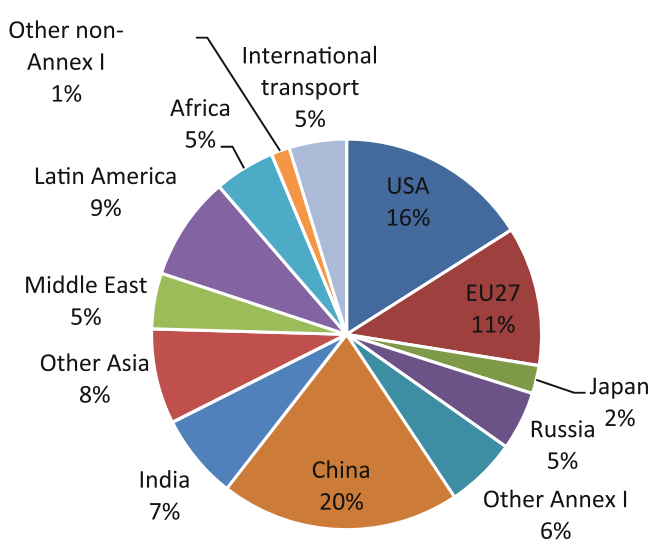

2050

Total= 73 trillion 2005US\$

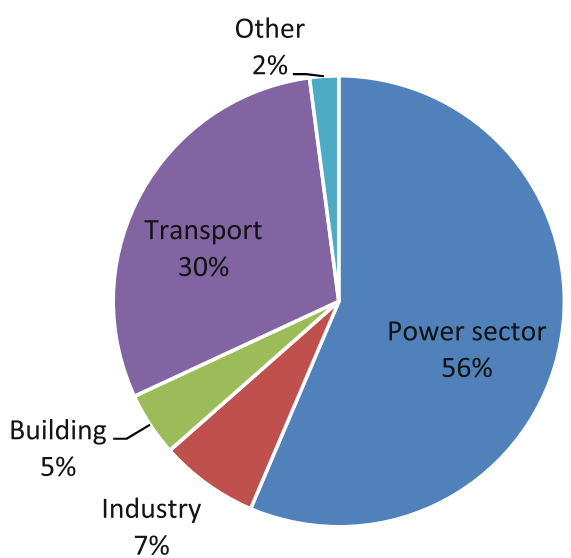

for a large share: these two countries, together, account for $46 \%$ of the total investment by 2020 and $36 \%$ of the total investment by 2050 .

In a sectoral breakdown, the power sector accounts for the largest share, followed by the transport sector (Fig. 17). The power generation and transport sectors account for 59 and $19 \%$ of the total additional investment by 2020, respectively. The large investment in FCV after 2035 pushes up additional investment in the transport sector remarkably, to $30 \%$ by 2050 .

Total technological cost

This section assesses the total technological cost. The total technological cost is composed of investment cost and operating cost, the latter of which includes energy cost and maintenance cost. Earlier, in "Investment cost," we presented quantitative estimates of the investment cost. Thus, our main focus here will be the operating cost and the sum of the investment cost and operating cost.

GHG mitigation technologies may affect the operating cost in two ways, by decreasing it or increasing it. Typical among technologies that decrease the operating cost is energy-saving technology, which lowers the annual energy cost by lowering energy consumption. Typical among technologies that increase operating cost are those that consume extra energy to reduce GHG emissions, such as CCS. Another cause of increased energy cost is fuel switching from low-cost to high-cost fuel: the switch from coal to natural gas, for example, may raise the energy cost.

Figure 18 shows the cumulative technological cost worldwide by 2050 in the s600 scenario relative to the reference scenario.

The two types of effect discussed above lead to different operating cost trends in different sectors. In the power sector, energy-saving, fuel-switching, and the introduction 

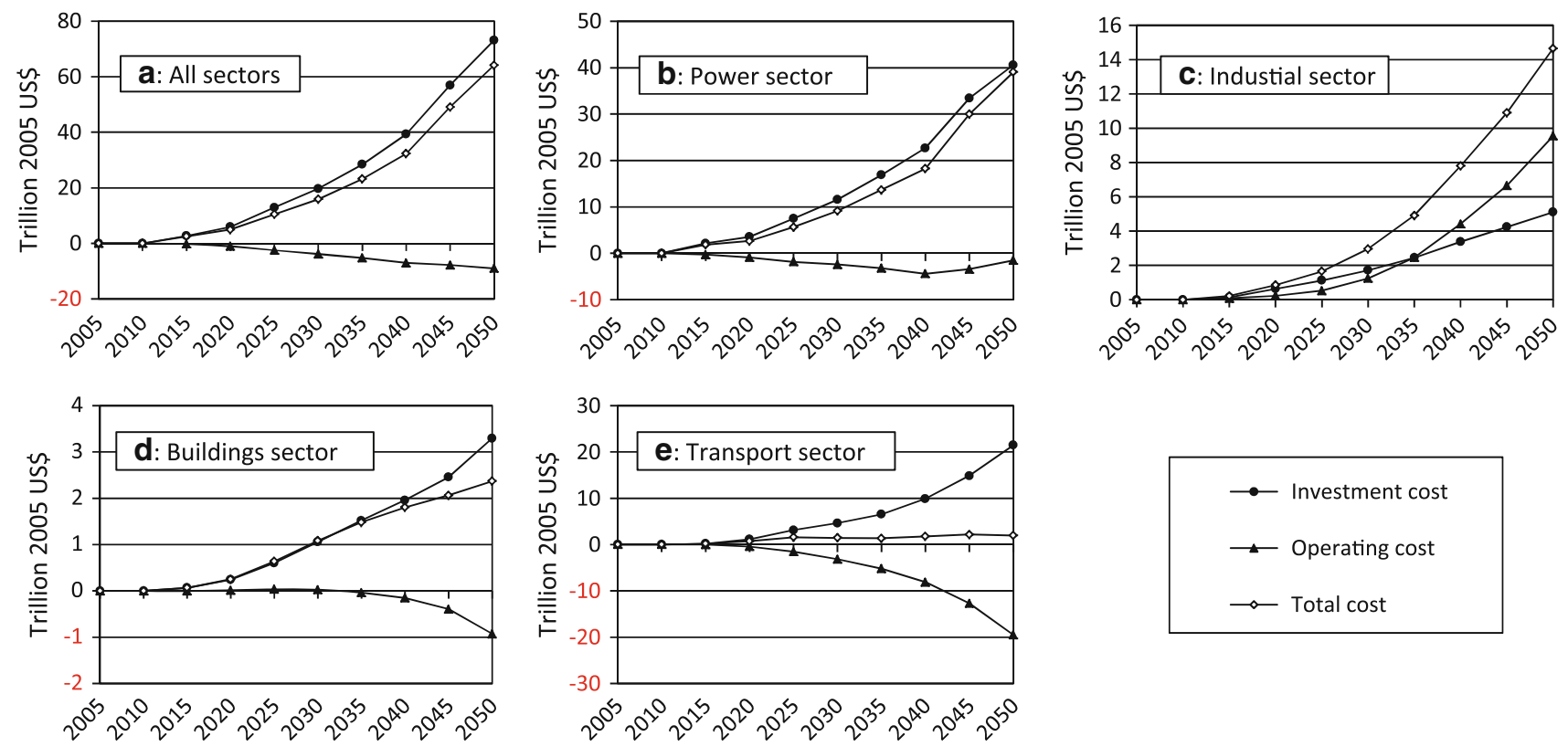

Fig. 18 Cumulative incremental technological cost in the s600 scenario

of CCS all take place in the s600 scenario. The mixed effect leads to a decrease in the operating cost by 2050 , but only a very small decrease relative to the increase of the investment cost. In the industrial sector, industries make the switch from coal to gas (see Fig. 11) and introduce CCS on a large scale in energy-intensive sectors such as iron, steel, and cement. As a consequence, the operating cost increases at an accelerated pace: by 2050 , the additional operating cost is 1.9 -fold higher than the additional investment cost. The operating cost in the buildings sector decreases over the long term, but this decrease is rather small relative to the increase of the investment cost.

In contrast, we see a different trend, a significant decrease in the operating cost, in the transport sector. $\mathrm{CO}_{2}$ reduction technologies in transport such as efficient ICEV, HEV, and FCV reduce energy consumption substantially, albeit at a high investment cost. This results in a substantial reduction in energy cost comparable to the incremental investment cost. From this, we see that most of the up-front investment in the transport sector can be paid back by annual energy cost savings over the lifetime of the technology.

\section{Conclusions}

In this article we examine the technological feasibility of the global target of reducing GHG emissions to $50 \%$ of the 1990 level by the year 2050 , a level roughly aligned with the climate target of $2{ }^{\circ} \mathrm{C}$. We also assess the transition of energy systems in major energy sectors such as power generation, industry, transport, and buildings. Lastly, we perform a detailed analysis of the contribution of low-carbon technologies to GHG emission reduction and evaluate the required technological cost. An important component of this study, a detailed assessment of technologies in energy and nonenergy sectors in mid- and long-term timeframes, sets it apart from other studies on the same topic.

The analysis leads to the following conclusions:

- The target of reducing GHG emissions by $50 \%$ from the 1990 level by the year 2050 is technically feasible, but will require great emission mitigation effort. The GHG emission reduction rates from the reference scenario stand at $23 \%$ in 2020 and $73 \%$ in 2050 . The marginal abatement cost to achieve these emission reductions reaches $\$ 150 / \mathrm{tCO}_{2}$-eq in 2020 and $\$ 600 /$ $\mathrm{tCO}_{2}$-eq in 2050 .

- The emission reduction target can be achieved by reducing energy intensity (energy consumption/GDP) by $55 \%$ and reducing carbon intensity $\left(\mathrm{CO}_{2}\right.$ emission/ energy consumption) by $75 \%$ by 2050 .

- Major changes in energy systems are required. For example, low/zero/negative-carbon technologies such as fossil fuel with CCS, wind, solar, and biomass with/ without CCS become dominant in the power generation sector by 2050.

- Energy saving and fuel switching, in combination with improvements in the emission factor of electricity, are key to achieving significant reductions in $\mathrm{CO}_{2}$ emissions in the final energy consumption sectors.

- Renewable energy, fuel switching, and efficiency improvement in thermal power generation account for 
$45 \%$ of the total GHG emission reduction in 2020. Non-energy sectors, namely, fugitive emission, waste management, agriculture, and F-gases, account for $25 \%$ of the total GHG emission reduction in the same year.

- CCS, solar power generation, wind power generation, biomass power generation, and biofuel collectively account for $64 \%$ of the total GHG emission reduction in 2050 .

- The required additional investment in GHG abatement technologies reaches US\$ 6.0 trillion by 2020 and US\$ 73 trillion by 2050 . These investments correspond to 0.7 and $1.8 \%$ of the world GDP, respectively, in these periods.

- Non-Annex I regions account for $55 \%$ of the total additional investment by 2050 .

- Among all sectors, the largest investment is required in power generation. The power generation sector accounts for $56 \%$ of the total additional investment by 2050 .

- The transport sector accounts for $30 \%$ of the total additional investment by 2050. Most of the investment in the transport sector, however, can be paid back through energy cost savings.

Acknowledgments This research was supported by the Environment Research and Technology Development Fund (S-6-1 and A-1103) of the Ministry of the Environment of Japan.

Open Access This article is distributed under the terms of the Creative Commons Attribution License which permits any use, distribution, and reproduction in any medium, provided the original author(s) and the source are credited.

\section{References}

Akashi O, Hanaoka T, Matsuoka Y, Kainuma M (2011) A projection for global $\mathrm{CO}_{2}$ emissions from the industrial sector through 2030 based on activity level and technology changes. Energy 36:1855-1867. doi:10.1016/j.energy.2010.08.016

Berndes G, Hoogwijk M, van den Broek R (2003) The contribution of biomass in the future global energy supply: a review of 17 studies. Biomass Bioenergy 25:1-28

Clarke L, Edmonds J, Krey V, Richels R, Rose S, Tavoni M (2009) International climate policy architectures: overview of the EMF22 international scenarios. Energy Econ 31:S64-S81. doi: 10.1016/j.eneco.2009.10.013

Dooley JJ, Dahowski RT, Davidson CL, Wise MA, Gupta N, Kim SH, Malone EL (2006) Carbon dioxide capture and geologic storage. Global Energy Technology Strategy Program

Edenhofer O, Knopf B, Barker T, Baumstark L, Bellevrat E, Chateau $B$, Criqui $P$, Isaac $M$, Kitous $A$, Kypreos $S$, Leimbach $M$, Lessmann K, Magne B, Scrieciu S, Turton H, van Vuuren DP (2010) The economics of low stabilization: model comparison of mitigation strategies and costs. Energy J 31(Special Issue 1): $11-48$
European Commission, Joint Research Centre (JRC)/Netherlands Environmental Assessment Agency (PBL) (2010) Emission Database for Global Atmospheric Research (EDGAR), release version 4.1

Fisher G, Schrattenholzer L (2001) Global bioenergy potentials through 2050. Biomass Bioenergy 20:151-159

Haberl H, Erb KH, Krausmann F (2007) Human appropriation of net primary production (HANPP). International Society for Ecological Economics, Internet Encyclopedia of Ecological Economics

Hanaoka T, Akashi O, Kanamori Y, Ikegami T, Kainuma M, Hasegawa T, Fujimori S, Matsuoka Y, Hibino G, Fujiwara K, Motoki Y (2009) Global greenhouse gas technological mitigation potentials and costs in 2020, 2nd edn. AIM Interim Report

Hendriks C, Graus W, van Bergen F (2004) Global carbon dioxide storage potential and costs. Ecofys, Utrecht

Hoogwijk M, Faaij A, van den Broek R, Berndes G, Gielen D, Turkenburg W (2003) Exploration of the ranges of the global potential of biomass for energy. Biomass Bioenergy 25:119-133

Hoogwijk M, Faaij A, Eickhout B, de Vries B, Turkenburg W (2005) Potential of biomass energy out to 2100 , for four IPCC SRES land-use scenarios. Biomass Bioenergy 29:225-257

Intergovernmental Panel on Climate Change (2007) Summary for policymakers. In: Metz B, Davidson OR, Bosch PR, Dave R, Meyer LA (eds) Climate change 2007: mitigation. Contribution of working group III to the fourth assessment report of the intergovernmental panel on climate change. Cambridge University Press, Cambridge

International Energy Agency (IEA) (2008) $\mathrm{CO}_{2}$ capture and storage, a key carbon abatement option. OECD/IEA, Paris

International Energy Agency (IEA) (2010) Energy technology perspectives 2010. OECD/IEA, Paris

Kainuma M, Matsuoka Y, Morita T (eds) (2003) Climate policy assessment: Asia-Pacific integrated modeling. Springer, Tokyo

Luckow P, Wise MA, Dooley JJ, Kim SH (2010) Large-scale utilization of biomass energy and carbon dioxide capture and storage in the transport and electricity sectors under stringent $\mathrm{CO}_{2}$ concentration limit scenarios. Int J Greenhouse Gas Control 4:865-877

Luderer G, Bosetti V, Jakob M, Leimbach M, Steckel J, Waisman H, Edenhofer O (2011) The economics of decarbonizing the energy system?-results and insights from the RECIPE model intercomparison. Climatic Change. doi:10.1007/s10584-0110105-x

Masui T, Ashina S, Fujino J (2010) Analysis of $4.5 \mathrm{~W} / \mathrm{m}^{2}$ stabilization scenarios with renewable energies and advanced technologies using AIM/CGE[Global] model. AIM Team. http://wwwiam.nies.go.jp/aim/reports_html/rpt/2010/cge_4.5W.pdf

Nakicenovich N, Alcamo J, Davis G, de Vries B, Fenhann J, Gaffin S, Gregory K, Grubler A, Jung TY, Kram T, Rovere ELL, Michaelis L, Mori S, Morita T, Pepper W, Pitcher H, Price L, Riahi K, Roehrl A, Rogner H-H, Sankovski A, Schlesinger M, Shukla P, Smith S, Swart R, van Rooijen S, Victor N, Dadi Z (2000) Special report on emissions scenarios. Cambridge University Press, Cambridge

Rhodes JS (2007) Carbon mitigation with biomass: an engineering, economic and policy assessment of opportunities and implications. Department of Engineering and Public Policy, PhD thesis, Carnegie Mellon University

Smeets E, Faaji A, Lewandowski I (2004) A quickscan of global bioenergy potentials to 2050. Report NWS-E-2004-109

Smeets EMW, Faaji APC, Lewandowski IM, Turkenburg WC (2007) A bottom-up assessment and review of global bio-energy potentials to 2050. Prog Energy Combust Sci 33:56-106

United Nations (UN) (2009) World population prospects: the 2008 revision. Population Division, Department of Economic and Social Affairs, United Nations 
United Nations Environment Programme (UNEP) (2010) The emissions gap report: are the Copenhagen accord pledges sufficient to limit global warming to $2^{\circ} \mathrm{C}$ or $1.5^{\circ} \mathrm{C}$ ? United Nations Environment Programme

Yamaji K, Matsuhashi M, Nagata Y, Kaya Y (1991) An integrated system for $\mathrm{CO}_{2}$ /energy/GNP analysis: case studies on economic measures for $\mathrm{CO}_{2}$ reduction in Japan. Workshop on $\mathrm{CO}_{2}$ reduction and removal: measures for the next century, 19-21 March 1991. International Institute for Applied Systems Analysis, Laxenburg, Austria 